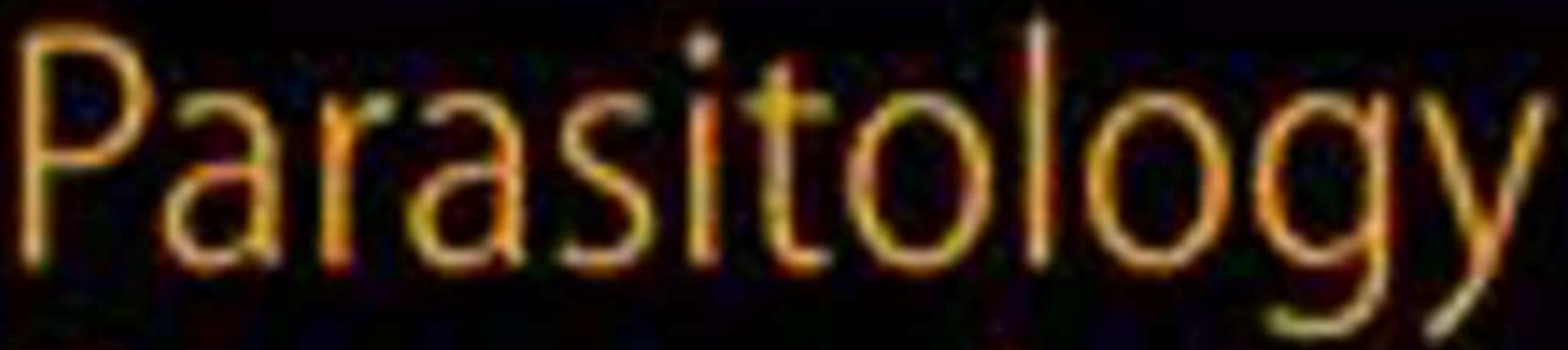
Research 


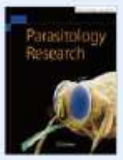

Parasitology Research

Founded as Zeitschrift für Parasitenkunde

Journal home, Editors

Editors

Editors-in-Chief:

Una Ryan

School of Veterinary and Life Sciences

Murdoch University, Perth Campus

Murdoch, Western Australia 6150

e-mail:una.ryan@murdoch.edu.au

\section{Julia Walochnik}

Molecular Parasitology

Medical University of Vienna

1090 Vienna, Austria

e-mail: julia.walochnik@meduniwien.ac.at

\section{Section Editors:}

\section{Arthropods and Medical Entomology}

Norbert Becker, German Mosquito Control Association (KABS), Speyer, Germany Neil Chilton, University of Saskatchewan, Saskatoon, Saskatchewan, Canada Guido Favia, UNICAM, Camerino, MC, Italy Helge Kampen, Federal Research Institute for Animal Health, Greifswald, Germany Boris Krasnov, Ben-Gurion University of the Negev, Midreshet Ben-Gurion, Israel Charlotte Oskam. Murdoch University, Murdoch, WA, Australia

Domenico Otranto, University of Bari, Valenzano, Italy

\section{Fish Parasitology}

Stephen A. Bullard (Ash), Auburn University, Auburn, AL, USA

Sascha Hallett, Oregon State University, Corvallis, OR, USA

Astrid Holzer, Czech Academy of Sciences, Ceske Budejovice, Czech Republic

Simonetta Mattiucci, University of Rome, Rome, Italy

Guillermo Salgado-Maldonado, Universidad Nacional Autonoma de Mexico, Ciudad

Universitaria, Mexico

Shokoofeh Shamsi, Charles Sturt University, Wagga Wagga, NSW, Australia

Christopher Whipps, State University of New York, Syracuse, NY, USA

\section{Genetics, Evolution, and Phylogeny}

Neil Chilton, University of Saskatchewan, Saskatoon, Saskatchewan, Canada Leonhard Schnittger, Instituto de Patobiologia, CICVyA and CONICET, Buenos Aires Argentina

Marta M.G. Teixeira. University of Sao Paulo, Brazil

Lihua Xiao, US Centers for Disease Control and Prevention (CDC), Atlanta, GA, USA

Xing-Quan Zhu, Chinese Academy of Agricultural Sciences, Lanzhou, PR China

\section{Helminthology (Medical and Veterinary)}

Bruce Conn, Berry College, Mount Berry, GA, USA

Christoph G. Grevelding, Justus-Liebig-University, Giessen, Germany

Georg von Samson-Himmelstjerna, Free University of Berlin, Berlin, Germany

Hiroshi Sato, Yamaguchi University, Yamaguchi, Japan

Elizabeth M. Warburton, Ben Gurion University of the Negev, Midreshet Ben Gurion, Israel

Dante S. Zarlenga, USDA. Animal Parasitic Diseases Lab, Beltsville, MD, USA

\section{Immunology and Host-Parasite Interactions}

Bruno Gottstein, University of Bern, Bern, Switzerland

Sarah Hendrickx, University of Antwerp, Wilrijk, Belgium

Nawal S.H. Hijiawi, The Hashemite University, Jordan

Dana Mordue, New York Medical College, Valhalla, NY, USA

Kalyanasundaram Ramaswamy, University of Illinois, Rockford, IL. USA

Tobili Sam-Yellowe, Cleveland State University, Cleveland, OH, USA

Sabine Specht, University of Zurich, Schlieren, Switzerland

\section{Protozoology (Medical and Veterinary)}

Berit Bangoura, University of Wyoming. Laramie, WY, USA

Yaoyu Feng, South China Agricultural University, Guangzhou, PR China

Sarah Hendrickx, University of Antwerp. Wilrijk, Belgium

Nawal S.H. Hijjawi, The Hashemite University, Jordan 
Daniel Howe, University of Kentucky, Lexington, KY, USA

Laryssa Howe, Massey University, Palmerston North, New Zealand

Panagiotis Karanis, Qinghai University, Xining, PR China, and University of Cologne,

Cologne, Germany

David Lindsay, Virginia Tech, Blacksburg, VA, USA

Kevin S.W. Tan, National University of Singapore, Singapore

Marta M.G. Teixeira, University of Sao Paulo, Brazil

Treatment and Prophylaxis

Kalyanasundaram Ramaswamy, University of Illinois, Rockford, IL USA

\section{Editorial Board:}

J.5. Ahmed, Borstel

G. Benelli, Pisa

X.G. Chen, Guangzhou

P.-H. Clausen, Berlin

A. Daugschies, Leipzig

J.-F. Dubremetz, Montpellier

R. Entzeroth, Dresden

A. Estrada-Peña, Zaragoza

H.-P. Fuehrer, Wien

F.A. Abdel Ghaffar, Cairo

U. Groß, Gottingen

A. Hörauf, Bonn

P. Holman, College Station

I. Igarashi, Obihiro

M.C. Jenkins, Beltsville

A. Joachim, Wien

S. Klimpel, Frankfurt/Main

M. Lanzer, Heidelberg

T. Laskay, Lúbeck

B. Loos-Frank, Stuttgart

P.T. Loverde, San Antonio

R. Lucius, Berlin

C. Luder, Gottingen

Z.R. Lun, Guangzhou

A. Mathis, Zurich

M. A Morales, Notre Dame

P. O'Donoghue, Brisbane

R. Pospischil, Monheim

1. Richter, Düsseldorf

G. Schaub, Bochum

Patrick L. Scheid, Koblenz

J. Schrével, Paris

A.A. Siddiqui, Lubbock

N. Singh, Punjab

W. Solbach, Lübeck

C. Strube, Hannover

A. Thompson Murdoch

A.G.M. Tielens, Utrecht

A. Turberg, Leverkusen

K. Williamson, Chicago

Z. Wu, Guangzhou

H. Yoshikawa, Nara

\section{@ Springer}

Publish with us

Authors \& Editors

Joumal authors

Publishing ethics

Open Access \& Springer

\section{Discover content}

Springertink

Books A-Z

Joumals $A-Z$

Video

\section{Other services}

Iristructors

Librarians (Springer Nature)

Societies and Publishing

Partners

Advertisers

Shop on Springer.com
About Springer

About us

Help \& Support

Contact us

Press releases

Impressum
Legal

General term \& conditions

Rights \& permission

Privacy

How we use cookies

Manage cookies

Accessibility

\section{SPRINGER NATURE}

(9) 2019 Springer Nature Switzerland AG. Part of Springer Nature 
$\underline{\text { Skip to main content }}$

\section{Springer Link}

Parasitology Research

All Volumes \& Issues

ISSN: 0932-0113 (Print) 1432-1955 (Online)

\section{Articles not assigned to an issue (42 articles)}

1. Protozoology - Original Paper

Three new species of Eimeria Schneider 1875 in the montane grass mouse, Akodon montensis (Rodentia: Cricetidae: Sigmodontinae), and redescription of Eimeria zygodontomyis Lainson and Shaw 1990 from southeastern Brazil

Marcos Tobias de Santana Miglionico, Lúcio André Viana...

2. Arthropods and Medical Entomology - Original Paper

Species diversity and molecular insights into phlebotomine sand flies in Sardinia (Italy)an endemic region for leishmaniasis

$\underline{\text { S. Carta, D. Sanna, F. Scarpa }}, \underline{\text { Antonio Varcasia }}, \underline{\text { L. Cavallo... }}$

3. Helminthology - Original Paper

Integrated taxonomic approaches to seven species of capillariid nematodes (Nematoda: Trichocephalida: Trichinelloidea) in poultry from Japan and Indonesia, with special reference to their $18 S \mathrm{rDNA}$ phylogenetic relationships

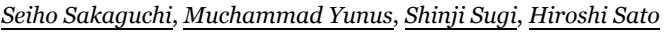

4. Protozoology - Short Communication

Genetic identification of the ciliates from greater rheas (Rhea americana) and lesser rheas (Rhea pennata) as Balantioides coli

$\underline{\text { Juan José García-Rodríguez, }}$ Rafael Alberto Martínez-Díaz...

5. Helminthology - Original Paper

Heteromorphism of sperm axonemes in a parasitic flatworm, progenetic Diplocotyle olrikii Krabbe, 1874 (Cestoda, Spathebothriidea)

Magdaléna Bruňanská, Martina Matoušková, Renáta Jasinská...

6. Protozoology - Review

An appraisal of oriental theileriosis and the Theileria orientalis complex, with an emphasis on diagnosis and genetic characterisation

Hagos Gebrekidan, Piyumali K. Perera, Abdul Ghafar, Tariq Abbas...

7. Protozoology - Original Paper

Novel genotypes and multilocus genotypes of Enterocytozoon bieneusi in two wild rat species in China: potential for zoonotic transmission

Bin-Ze Gui, Yang Zou, Yi-Wei Chen, Fen Li, Yuan-Chun Jin...

8. Helminthology - Original Paper

In vitro apoptotic effect on human lymphatic filarial parasite by piperidine derivatives and thymidine reversal study

Priyanka S. Bhoj, Sahitya Rao, Sandeep P. Bahekar...

9. Protozoology - Short Communication

Atypical Toxoplasma gondii genotype from a sheep and a pig on Fernando de Noronha Island, Brazil, showed different mouse virulence profiles

Renata Pimentel B. Melo, Jonatas C. Almeida, Débora C. V. de Lima... 
10. Immunology and Host-Parasite Interactions - Short Communication

Renin angiotensin system molecules and nitric oxide local interactions in the adrenal gland of Trypanosoma cruzi infected rats

Aline Silva Miranda, Elizabeth R. S. Camargos...

11. Genetics, Evolution, and Phylogeny - Short Communication

Molecular detection and genotype distribution of Enterocytozoon bieneusi in farmed silver foxes (Vulpes vulpes) and arctic foxes (Vulpes lagopus) in Shandong Province, eastern China

$\underline{\text { Yuan-Yuan Ma, Yang Zou, Ye-Ting Ma, Lan-Bi Nie, }}$ Shi-Chen Xie...

12. Helminthology - Original Paper

Morphological comparison of genetically differentiated Polymorphus cf. minutus types

$\underline{\text { Daniel Grabner, Annemie Doliwa, Jana Bulantová, }}$ Petr Horák...

13. Immunology and Host-Parasite Interactions - Original Paper

Variation in parasitoidism of Protocalliphora azurea (Diptera: Calliphoridae) by Nasonia vitripennis (Hymenoptera: Pteromalidae) in Spain

Jorge Garrido-Bautista, Gregorio Moreno-Rueda, Arturo Baz...

14. Arthropods and Medical Entomology - Original Paper

Insights into the impact of Ivermectin on some protein aspects linked to Culex pipiens digestion and immunity

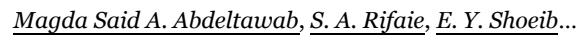

15. Fish Parasitology - Short Communication

Are glial cells of the Digenea (Platyhelminthes) muscle cells?

Larisa G. Poddubnaya, David I. Gibson

16. Immunology and Host-Parasite Interactions - Original Paper

Metabolic requirements of Besnoitia besnoiti tachyzoite-triggered NETosis

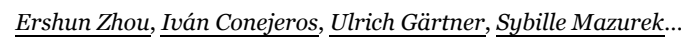

17. Arthropods and Medical Entomology - Original Paper

The Ixodes ricinus complex (Acari: Ixodidae) in the Southern Cone of America: Ixodes pararicinus, Ixodes aragaoi, and Ixodes sp. cf. I. affinis.

María N. Saracho-Bottero, José M. Venzal, Evelina L. Tarragona...

18. Protozoology - Short Communication

Improving the sensitivity of an hsp2o-based PCR for genus detection of Leishmania parasites in cutaneous clinical samples: a proof of concept

$\underline{\text { Ana M. Montalvo, Annia Alba, }}, \underline{\text { Jorge Fraga }}, \underline{\text { Ana Marzoa }}, \underline{\text { Cecia Torres... }}$

19. Arthropods and Medical Entomology - Original Paper

Can data from native mosquitoes support determining invasive species habitats?

Modelling the climatic niche of Aedes japonicus japonicus (Diptera, Culicidae) in Germany

$\underline{\text { Antje Kerkow, }}$ Ralf Wieland, Linus Früh, Franz Hölker...

20. Genetics, Evolution, and Phylogeny - Original Paper

Molecular detection of Cryptosporidium and Enterocytozoon bieneusi in dairy calves and sika deer in four provinces in Northern China

Wei-Fu Tao, Hong-Bo Ni, Hong-Feng Du, Jing Jiang, Jiao Li... 
Integrated taxonomic approaches to seven species of capillariid nematodes (Nematoda: Trichocephalida:

Trichinelloidea) in poultry from Japan and Indonesia, with special reference to their $18 S$ rDNA phylogenetic relationships Seiho Sakaguchi, Muchammad Yunus, Shinji Sugi \& Hiroshi Sato

Parasitology Research Founded as Zeitschrift für Parasitenkunde

ISSN 0932-0113

Parasitol Res

DOI 10.1007/s00436-019-06544-y

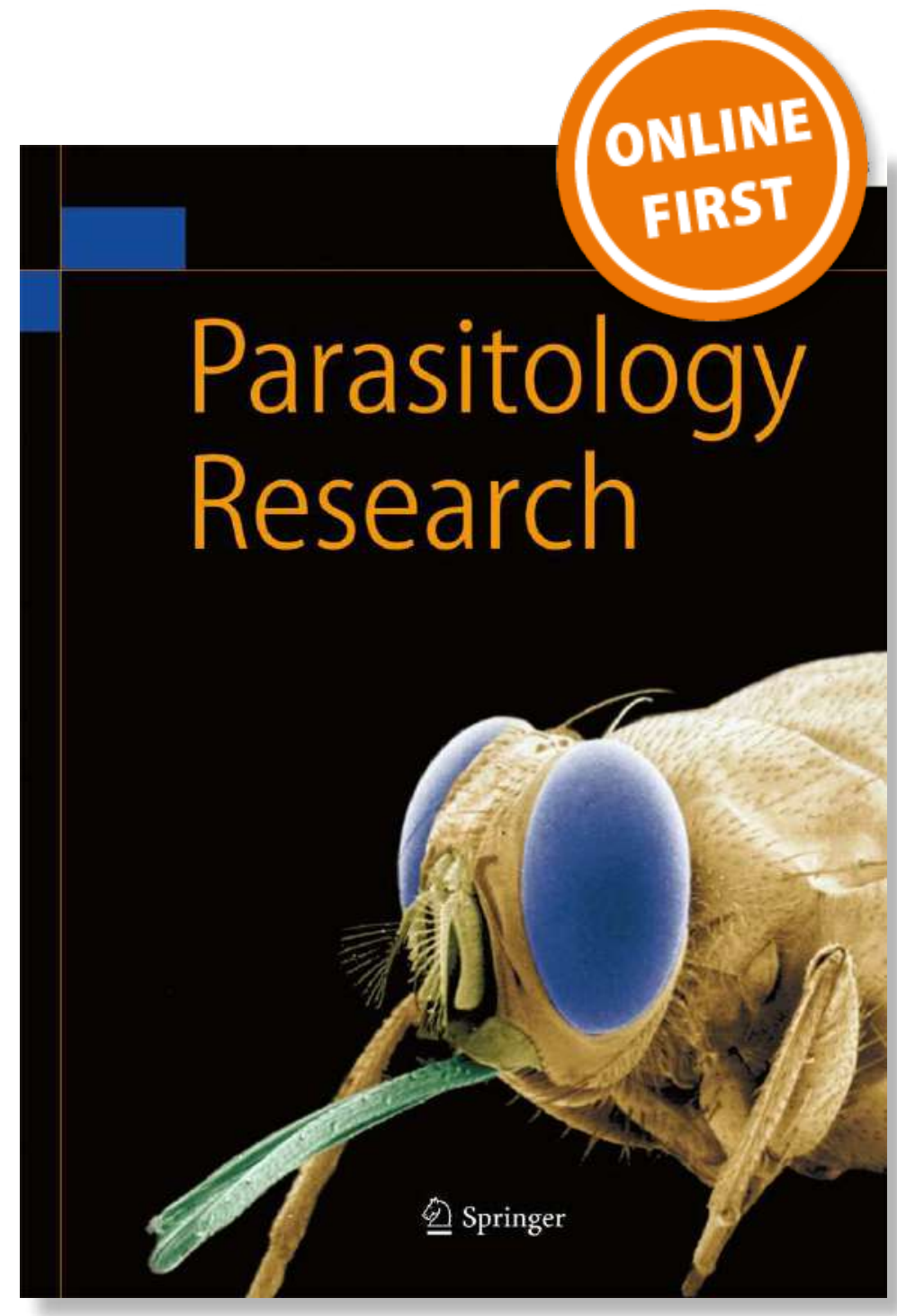

望 Springer 
Your article is protected by copyright and all rights are held exclusively by SpringerVerlag GmbH Germany, part of Springer Nature. This e-offprint is for personal use only and shall not be self-archived in electronic repositories. If you wish to self-archive your article, please use the accepted manuscript version for posting on your own website. You may further deposit the accepted manuscript version in any repository, provided it is only made publicly available 12 months after official publication or later and provided acknowledgement is given to the original source of publication and a link is inserted to the published article on Springer's website. The link must be accompanied by the following text: "The final publication is available at link.springer.com". 


\title{
Integrated taxonomic approaches to seven species of capillariid nematodes (Nematoda: Trichocephalida: Trichinelloidea) in poultry from Japan and Indonesia, with special reference to their $18 \mathrm{~S}$ rDNA phylogenetic relationships
}

\author{
Seiho Sakaguchi ${ }^{1} \cdot$ Muchammad Yunus $^{2} \cdot$ Shinji Sugi $^{3} \cdot$ Hiroshi Sato $^{1,2,3}$ (D) \\ Received: 26 January 2019 / Accepted: 6 November 2019 \\ (C) Springer-Verlag GmbH Germany, part of Springer Nature 2019
}

\begin{abstract}
Morphological and genetic analyses were performed on seven species of the family Capillariidae (Nematoda: Trichocephalida: Trichinelloidea), viz. Eucoleus perforans, Eucoleus contortus, Aonchotheca bursata, Baruscapillaria obsignata, Capillaria anatis, Capillaria phasianina, and Capillaria spinulosa, detected in poultry from Japan and Indonesia. Two Eucoleus spp., perforating the esophageal mucosa of the Japanese green pheasant farmed in Japan (E. perforans) and domestic goose in Indonesia (E. contortus), were morphologically characterized. Furthermore, we observed substantial nucleotide differences between their $18 \mathrm{~S}$ ribosomal RNA gene (rDNA), revealing maximum identity (97.27\%) over the 1797-bp length. Similarly, B. obsignata in the small intestine of Japanese green pheasants in Japan, a chicken, geese, domestic pigeons, and a turkey in Indonesia, and $C$. anatis in the ceca of chickens in Indonesia were morphologically and molecular-genetically compared with previously reported isolates of these species in Japan. Aonchotheca bursata collected from the small intestine of the Japanese green pheasant was also molecular-genetically characterized for the first time; however, sequencing of the 18S rDNA of C. phasianina from the cecum of the same bird was unsuccessful. Capillaria worms in the ceca of a domestic duck and geese in Indonesia were identified as $C$. spinulosa, which had only previously been recorded in wild birds of the Anseriformes in the Palaearctic region. Morphologically, this species was closest to Capillaria pudendotecta recorded from the ceca of wild and captive swans, except for the lack of vaginal appendages in female worms and shorter esophagi relative to the body length in both male and female worms. Phylogenetically, these two species were closely related, although substantial nucleotide changes were noted. The 18S rDNA nucleotide sequences of the species isolated here were consistent with the recent taxonomic system established for Capillariidae based primarily on the morphology of male caudal ends.
\end{abstract}

Keywords Eucoleus perforans $\cdot$ Eucoleus contortus $\cdot$ Aonchotheca bursata Baruscapillaria obsignata $\cdot$ Capillaria anatis . Capillaria phasianina $\cdot$ Capillaria spinulosa $\cdot$ Capillariidae $\cdot$ Poultry $\cdot 18 \mathrm{~S}$ rDNA

$\overline{\text { Seiho Sakaguchi and Muchammad Yunus contributed equally to this }}$ work.

Section Editor: Georg von Samson-Himmelstjerna

Hiroshi Sato

sato7dp4@yamaguchi-u.ac.jp

1 Laboratory of Parasitology, Joint Faculty of Veterinary Medicine, Yamaguchi University, 1677-1 Yoshida, Yamaguchi 753-8515, Japan

2 Department of Parasitology, Faculty of Veterinary Medicine, Airlangga University, Campus C, Mulyorejo, Surabaya 60115, Indonesia

3 United Graduate School of Veterinary Science, Yamaguchi University, 1677-1 Yoshida, Yamaguchi 753-8515, Japan

\section{Introduction}

Members of the family Capillariidae Railliet, 1915 (Nematoda: Trichocephalida: Trichinelloidea) are thin, thread-like nematodes with long characteristic esophagi comprising a short muscular part and a long glandular part (termed the stichosome) and lemon- or barrel-shaped eggs with pluglike structures on both ends (Gibbons 2010; Hodda 2011). There are approximately 390 nominal species recorded from a variety of organs/tissues and a wide range of hosts, such as fish, amphibians, reptiles, birds, and mammals, including humans (Moravec 2001; Hodda 2011). However, the taxonomic identification of capillariid nematodes is fairly difficult 
as fragile thin worms are required to undergo robust laboratory manipulation for morphological observation. Additionally, limited microscopic resolution can hinder the observation of very fine structures of thin worms (Anderson 1992).

In an earlier study from our laboratory (Tamaru et al. 2015), we performed morphological and molecular genetic characterizations of four avian species of the family Capillariidae and assessed as far as was possible the validity of the latest classification of the family following Moravec's redefinition of its genera in 1982 based on the male caudal end as the most important morphological feature for separating the genera (Moravec 1982; Gibbons 2010). In that study, we characterized three Capillaria spp., i.e., Capillaria anatis (Schrank 1790) Travassos 1915, Capillaria pudendotecta Lubimova 1947, and Capillaria madseni Wakelin, Schmidt et Kuntz 1970, and Baruscapillaria obsignata (Madsen 1945) Moravec 1982 collected from chickens (Gallus gallus domesticus (Linnaeus 1758)), captive swans (Cygnus olor (Gmelin 1789) and Cygnus atratus (Latham 1790)), and carrion and jungle crows (Corvus corone Linnaeus 1758 and Corvus macrorhynchos Wagler 1827) in Japan and the Philippines; and several species of the genera Aonchotheca López-Neyra 1947, Pearsonema Freitas et Mendona 1960, and Eucoleus Dujardin 1845 from mammalian hosts. Because the family currently contains 27 genera (Gibbons 2010), the coverage of phylogenetic relationships of genera and species within Capillariidae is rather minimal and requires expansion.

Accordingly, in the current study, we collected eight capillariid species (two Eucoleus spp., one Aonchotheca sp., one Baruscapillaria sp., and three Capillaria spp.) from avian hosts in Japan and Indonesia, and analyzed these species from integrated taxonomic viewpoints, i.e., morphologically and genetically based on the $18 \mathrm{~S}$ ribosomal RNA gene (rDNA).

\section{Materials and methods}

\section{Parasite collection and morphological examination}

Five farmed Japanese green pheasants (Phasianus colchicus versicolor (Vieillot 1825)) were obtained on September 28, 2016, to diagnose the causative agent(s) of crop inflammation. The birds came from a farm located in Hitoyoshi City, Kumamoto Prefecture, southern Japan, which maintains approximately 350 parent pheasants with an annual production of more than 4000 yearling pheasants for release into the wild in early autumn (approximately 90 days old at release). During the periods from September 21 to 25 and December 9 to 17, 2017, six common pigeons (Columba livia Gmelin 1789), 16 domestic chickens (Gallus gallus domesticus), six domestic ducks (Anas platyrhynchos var. domesticus (Linnaeus 1758)), 11 geese (Anser cygnoides domesticus
(Linnaeus 1758)), and a domestic turkey (Meleagris gallopavo Linnaeus 1758) were obtained as living birds at wet markets in Surabaya City, Indonesia.

The birds were dissected on the day after euthanasia according to the guidelines for animal experiments outlined by the university, and helminth parasites were collected according to standard procedures (Tamaru et al. 2015). The collected parasites were preserved in either $10 \%$ neutral-buffered formalin solution or $70 \%$ ethanol and were categorized by host organ, parasite sex, and certain morphological characters under a dissection microscope. Intensive morphological analysis of fixed specimens was performed under a light microscope at high magnifications and partially by scanning electron microscopy (SEM). The processing procedure for SEM was similar to that detailed in an earlier report (Tran et al. 2015). Figures were drawn with the aid of a camera lucida. Measurements were performed on these drawn figures using a digital curvimeter type S (Uchida Yoko, Tokyo, Japan) when necessary and are expressed in millimeters as ranges, with means \pm standard deviations (SD) in parentheses. The collected specimens were deposited in the National Museum of Nature and Science, Tokyo, Japan (specimen numbers NSMT-As4476-As4503).

\section{DNA extraction, polymerase chain reaction, and sequencing}

The DNA of male and/or female worms of different species, stored in $70 \%$ ethanol, was extracted using an Illustra ${ }^{\mathrm{TM}}$ tissue and cells genomicPrep Mini Spin Kit (GE Healthcare UK, Buckinghamshire, UK) according to the manufacturer's instructions. PCR amplification of overlapping fragments of $18 \mathrm{~S}$ rDNA was performed as described previously (Tamaru et al. 2015). For some worms, two forward primers, i.e., S.r.18S-SSU22F and S.r.18S-SSU23F, were used instead of the primer NSF573/19 described by Tamaru et al. (2015). Table 1 summarizes all the forward and reverse universal eukaryotic primers employed in the current study. The DNA polymerase was Blend Taq-Plus(TOYOBO, Kita-ku, Osaka, Japan), and PCRs were conducted in a thermal cycler in 20 - or $25-\mu \mathrm{L}$ reactions using the following cycling protocol: 2 min at $94{ }^{\circ} \mathrm{C}$; followed by 40 cycles at $94{ }^{\circ} \mathrm{C}$ for $30 \mathrm{~s}, 64$ or $62{ }^{\circ} \mathrm{C}$ for $30 \mathrm{~s}$, and $72{ }^{\circ} \mathrm{C}$ for $90 \mathrm{~s}$; and final extension at $72{ }^{\circ} \mathrm{C}$ for $7 \mathrm{~min}$. The PCR products were purified using a FastGene Gel/PCR Extraction Kit (NIPPON Genetics Co., Tokyo, Japan) and sequenced directly with the primers for amplification and sequencing as described by Tamaru et al. (2015). When direct sequencing was not satisfactory, the purified PCR products were cloned into a plasmid vector, pTA2 (TArget Clone ${ }^{\mathrm{TM}}$; TOYOBO), and transformed into Escherichia coli JM109 cells (TOYOBO) according to the manufacturer's instructions. Following propagation, the plasmid DNA was extracted using a FastGene Plasmid Mini Kit (NIPPON Genetics Co.), and inserts from at least three independent clones were 
Table 1 Primers used to amplify and sequence overlapping segments of the $18 \mathrm{~S}$ rDNA of Capillariidae worms

\begin{tabular}{llll}
\hline Primer name $^{\mathrm{a}}$ & \multicolumn{2}{c}{ Nucleotide sequences } & Position of 5'-end $^{\text {b }}$ \\
\hline \multicolumn{2}{l}{ Primers for amplification and sequencing of DNA fragments } \\
F: & NSF4/18 & 5'-CTGGTTGATCCTGCCAGT-3' & 1 \\
F: & NSF573/19 & 5'-CGCGGTAATTCCAGCTCCA-3' & 595 \\
F: & S.r.18S-SSU22F & 5'-TCCAAGGAAGGCAGCAGGC-3' & 436 \\
F: & S.r.18S-SSU23F & 5'-ATTCCGATAACGAG & 1344 \\
& & CGAGACT-3' & 1243 \\
R: & 18S-1192R/20 & 5'-CAGGTGAGTTTTCCCGTGTT-3' & 1475 \\
R: & NSR1438/20 & 5'-GGGCATCACAGACCTGTTAT-3' & 1683 \\
R: & NSR1787/18 & 5'-CGACGGGCGGTGTGTACA-3' & 1848 \\
R: & S.r.18S-SSU18R & 5'-TGATCCTTCYGCAGGTTCAC-3' & \\
Primers for only sequencing of DNA fragments & 422 \\
R: & NSR581/18 & 5'-TCTCAGGCTCCCTCTCCGG-3' & 1196 \\
F: & NSF1179/18 & 5'-AATTTGACTCAACACGGG-3' & \\
\hline
\end{tabular}

${ }^{\mathrm{a}} \mathrm{F}$ : forward, R: reverse

${ }^{\mathrm{b}}$ The relative position of $5^{\prime}$-end of each primer in Baruscapillaria obsignata rDNA sequence (DDBJ/EMBL /GenBank accession no. LC052336). The $5^{\prime}$-end of NSF4/18 primer is considered as the beginning of $18 \mathrm{~S}$ rDNA here sequenced using universal M13 forward and reverse primers. The nucleotide sequences reported in the current study are available from the DDBJ/EMBL/GenBank databases under the accession numbers LC424996-LC425006.

\section{Phylogenetic analysis}

For phylogenetic analysis, the newly obtained $18 \mathrm{~S}$ rDNA sequences of capillariid worms collected in the current study and those of the same family retrieved from the DDBJ/EMBL/ GenBank databases were aligned using the CLUSTAL W multiple alignment program (Thompson et al. 1994), with subsequent manual adjustment. Regions judged to be poorly aligned and characters with a gap in any sequence were excluded from subsequent analyses; 1515 characters, of which 427 were variable, remained for subsequent analysis. Maximum likelihood (ML) analysis was performed with the program PhyML (Guindon and Gascuel 2003; Dereeper et al. 2008) provided on the "phylogeny.fr" website (http://www. phylogeny.fr/). The probability of inferred branches was assessed by the approximate likelihood ratio test, an alternative to the non-parametric bootstrap estimation of branch support (Anisimova and Gascuel 2006).

\section{Results}

\section{Sample collection}

Male and female worms of Capillariidae were collected from the esophagus including the crop; small intestine; and cecum of pheasants, pigeons, chickens, ducks, geese, and a turkey.
Based on the morphology of the male caudal end and female vulval position and appendages, along with the parasite location (organs and tissues) and other morphometric features, the collected nematodes were divided into seven species classified into the genera Eucoleus, Aonchotheca, Baruscapillaria, or Capillaria (Table 2).

\section{Morphological observation}

\section{Eucoleus perforans (Kotlan et Orosz 1931) López-Neyra 1946}

From the mucosa of the esophagus, particularly the crop, of four (80\%) Japanese green pheasants, 4-52 worms were collected from each host. The whole lengths of these worms were deeply embedded in the mucosal epithelium. Posterior ends of male worms were slightly tapered, and the extremities ended in a pseudobursa under light microscopy; two rounded dorsolateral lobes, each having a relatively large protrusion on its ventral surface and a dorsal papilla-like protrusion on each side, were observed (Fig. 1). Spicules were slender and indistinct owing to insufficient sclerotization. The spicular sheath was long and covered with cuticular spines. Posterior ends of female worms were slightly tapered and rounded, and the anus was situated terminally. The vulva had no appendages. Eggs were barrel-shaped with a smooth surface. Measurements are shown in Table 3.

Remarks: According to Baruš and Sergejeva (1989b), all capillariid species localized in the upper digestive tract of birds, such as the mucosal linings of the oral cavity, esophagus, and stomach, are classified in the genus Eucoleus, and they recognized only five valid species of the genus in a variety of avian species of the Palaearctic region: E. annulatus 
Table 2 Worm recovery from poultry examined in the present study

\begin{tabular}{|c|c|c|c|c|c|c|}
\hline Parasite species & Host & Parasite location & Prevalence $^{\mathrm{a}}$ & Intensity $^{\mathrm{b}}$ & Male worm ${ }^{\mathrm{c}}$ & Female worm $^{\mathrm{c}}$ \\
\hline Eucoleus perforans & Pheasant & Esophagus & $4 / 5$ & 4-52 (21.3) & $0-8(14)$ & $3-44(71)$ \\
\hline Eucoleus contortus & Goose & Esophagus & $3 / 11$ & $3-11(6.0)$ & $1-7(11)$ & $1-4(7)$ \\
\hline Aonchotheca bursata & Pheasant & Small intestine & $3 / 5$ & $1-4(2.7)$ & $0-1(2)$ & $1-3(6)$ \\
\hline \multirow[t]{5}{*}{ Baruscapillaria obsignata } & Pheasant & Small intestine & $3 / 5$ & $3-4(3.7)$ & $1-2(4)$ & $2-3(7)$ \\
\hline & Pigeon & Small intestine & $3 / 6$ & 4 & 2 & 2 \\
\hline & Goose & Small intestine & $3 / 11$ & $7-9(8.0)$ & $2(4)$ & $5-7(12)$ \\
\hline & Chicken & Small intestine & $1 / 16$ & $4-131(80.0)$ & $1-45(85)$ & $3-86(155)$ \\
\hline & Turkey & Small intestine & $1 / 1$ & 26 & 14 & 12 \\
\hline Capillaria anatis & Chicken & Cecum & $3 / 16$ & $3-5(4.0)$ & $0-2(4)$ & $1-5(7)$ \\
\hline Capillaria phasianina & Pheasant & Cecum & $2 / 5$ & $2-3(2.5)$ & $1(2)$ & $1-2(3)$ \\
\hline \multirow[t]{2}{*}{ Capillaria spinulosa } & Duck & Cecum & $1 / 6$ & 4 & 3 & 1 \\
\hline & Goose & Cecum & $3 / 11$ & $1-6(3.0)$ & $1-3(5)$ & $0-3(4)$ \\
\hline
\end{tabular}

${ }^{a}$ Number of positive birds / Number of examined birds

${ }^{\mathrm{b}}$ Range (average) of worm numbers in infected birds

${ }^{\mathrm{c}}$ Range (total) of worm numbers in infected birds

(Molin 1858) López-Neyra 1947, E. contortus, E. dispar (Dujardin 1845) López-Neyra 1947, E. obtusiuscula (Rudolphi 1819) Baruš et Sergejeva 1982, and E. perforans. Three of these species, i.e., E. annulatus, E. contortus, and E. perforans, are frequently isolated from the crop of domestic birds (chicken, turkey, goose, grouse, guinea fowl, partridge, pheasant, pigeon, and quail) when investigating the cause of high pathogenicity, i.e., serious inflammation of crops with heavy infection (Saif 2008). Eucoleus dispar and E. obtusiuscula are species parasitic to terrestrial birds of various orders and aquatic birds of Charadriiformes and Gruiformes, respectively (Baruš and Sergejeva 1989b). The

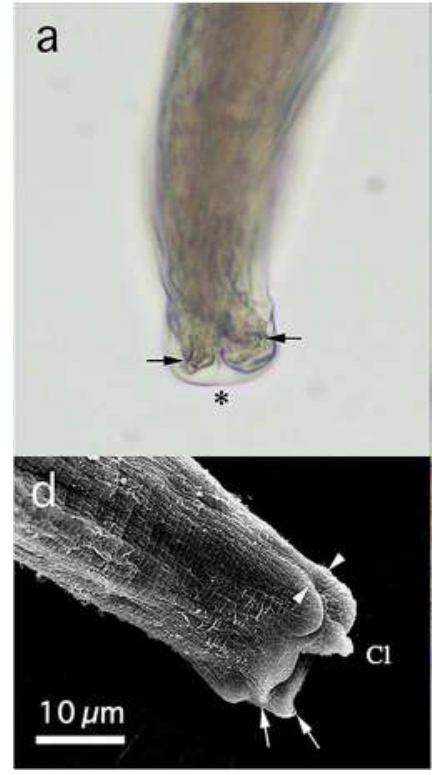

Fig. 1 Morphology of Eucoleus perforans from Japanese green pheasants analyzed by light microscopy $(\mathbf{a}-\mathbf{c}, \mathbf{e})$ and SEM $(\mathbf{d}, \mathbf{f})$. a Dorsal view of the caudal end of a male worm with a pseudobursa (asterisk) and two dorsal papilla-like protrusions (arrows). b Ventrolateral view of the caudal end of a male worm with cuticular expansion of the pseudobursa (asterisk). Close to the cloaca $(\mathrm{Cl})$, ventral protrusions, one each (white arrow), are situated on two dorsolateral

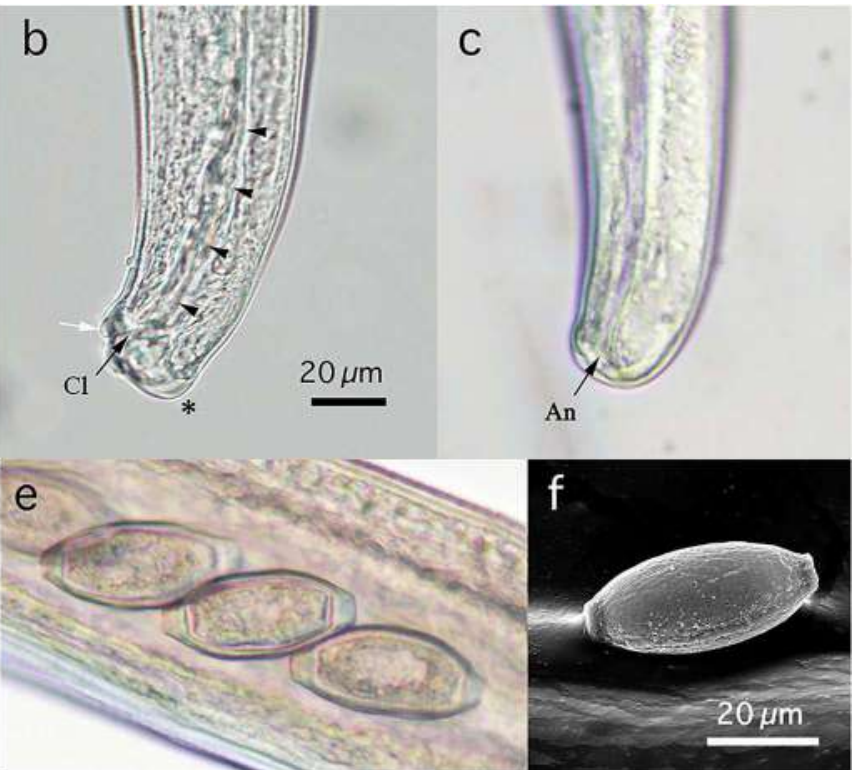

lobes. Black arrowheads indicate spines on inverted spicular sheath. c Caudal end of a female worm with a terminal anus (An). d SEM view of the caudal end of a male worm demonstrating the cloaca $(\mathrm{Cl})$, ventral protrusions on two dorsolateral lobes (arrowheads), and dorsal papillalike protrusions (arrows). e Intrauterine eggs with smooth surfaces. f SEM view of smooth eggshell surface. All photographs by light microscopy are at the same magnification and the scale bar is shown in $\mathbf{b}$ 
Table 3 Measurements of Eucoleus spp. dwelling in the esophageal mucosa of poultry

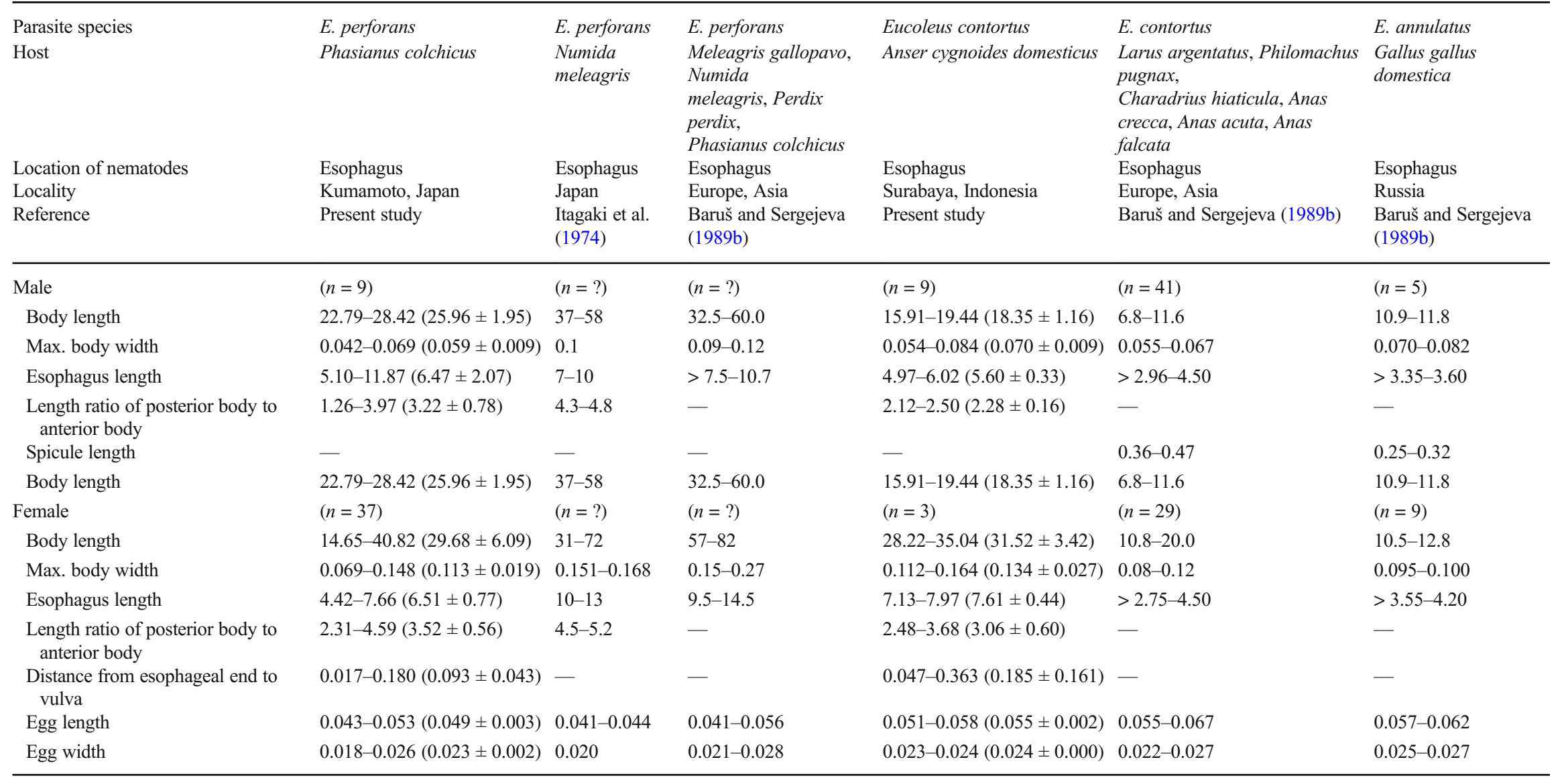


morphology of the current species coincided well with that of $E$. perforans, with particular reference to the lack of a cuticular swelling at the head (typical for E. annulatus), indistinct spicules, wide expansion of fine spines on the spicular sheath (limited areas in other species), and smooth eggshell surface (granular, spotted, or striated surface in other species).

\section{Eucoleus contortus (Creplin 1839) Gagarin 1951}

From the mucosa of the esophagus, particularly the crop, of three geese (27.3\%), 3-11 worms were collected from each host. The whole lengths of these worms were deeply embedded in the mucosal epithelium. The morphological features of male and female worms of $E$. contortus were almost identical to those of $E$. perforans except that the eggs were larger (0.051-0.058 $\mathrm{mm}$ versus $0.043-0.053 \mathrm{~mm}$ in length, respectively) with a different eggshell surface (finely granular versus smooth, respectively) as shown in Fig. 2 and Table 3. Spicules were slender and indistinct owing to insufficient sclerotization. The spicular sheath was long and densely covered with cuticular spines.

Remarks: As described by Baruš and Sergejeva (1989b), E. contortus is cosmopolitan in distribution and has been isolated from a great variety of birds, including domestic geese. Madsen (1951) stated that E. contortus and $E$. perforans had no substantial morphological differences; thus, the latter should be a junior synonym of $E$. contortus.
Baruš and Sergejeva (1989b) emphasized, however, the need to observe very carefully certain special characteristics that had only rarely been used in the past to distinguish the species, e.g., bacillary bands and structure of the external surface of eggs. Since the eggshell surface of the current specimens was finely granular (Fig. 2), contrary to the smooth surface of E. perforans (Fig. 1), we could identify the species as E. contortus with reference to Baruš and Sergejeva (1989b). As demonstrated later, the specimens from Japanese pheasants and geese, i.e., E. perforans and E. contortus, were actually differentiated by a phylogenetic analysis based on their $18 \mathrm{~S}$ rDNA nucleotide sequences, which revealed a maximal $97.27 \%$ (1748/1797) identity with two insertion/deletion (indel) base positions.

\section{Aonchotheca bursata (Freitas et Almeida 1934) López-Neyra 1947}

From the small intestines of three (60\%) Japanese green pheasants, one or two worms were collected from each host. Male worms were characterized by the presence of distinct precloacal caudal alae (Fig. 3), a small membranous bursa supported by two digitate processes of different lengths on each side (total of four), and a nonspinous spicular sheath with transverse convolutions. Female worms had a subterminal anus, semicircular transparent structures around the opening

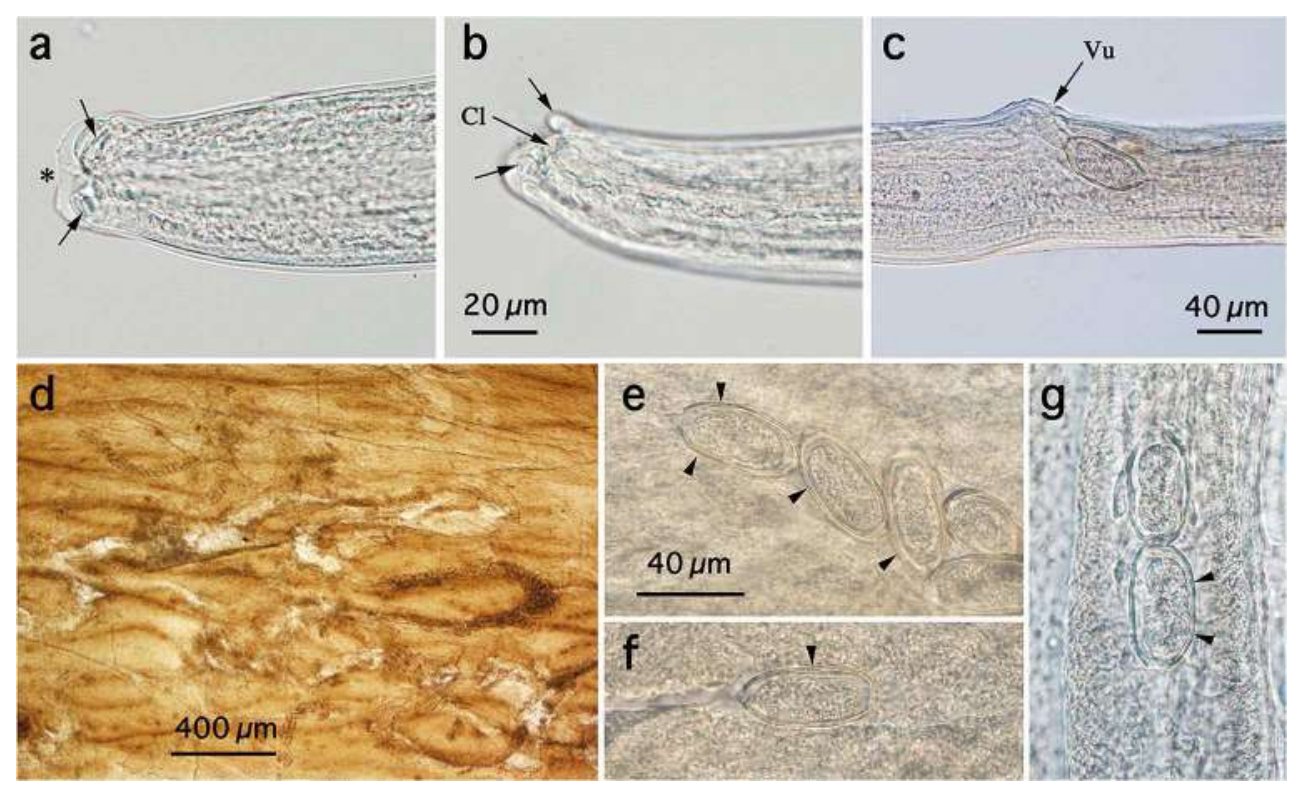

Fig. 2 Morphology of Eucoleus contortus from domestic geese in Surabaya, Indonesia. a Dorsal view of the caudal end of a male worm with a pseudobursa (asterisk) and two dorsal papilla-like protrusions (arrows). b Ventrolateral view of the caudal end of a male worm with two ventral protrusions (arrows) on lateral lobes close to the cloaca $(\mathrm{Cl})$. $\mathbf{c}$ No appendages around the vulva ( $\mathrm{Vu}$ ). $\mathbf{d}$ Epithelial sheet of the crop showing remarkable destruction of stratified squamous epithelium structures by undulating worm tracts (void areas) and deposited eggs. e, f Deposited eggs with finely granular surfaces in the crop epithelium (evident sites are indicated by arrowheads). $\mathrm{g}$ Intrauterine egg with finely granular surface (evident sites are indicated by arrowheads). Photographs $\mathbf{a}$ and $\mathbf{b}$ are at the same magnification and the scale bar is shown in $\mathbf{b}$. Photographs $\mathbf{e}-\mathbf{g}$ are at the same magnification and the scale bar is shown in $\mathbf{e}$ 


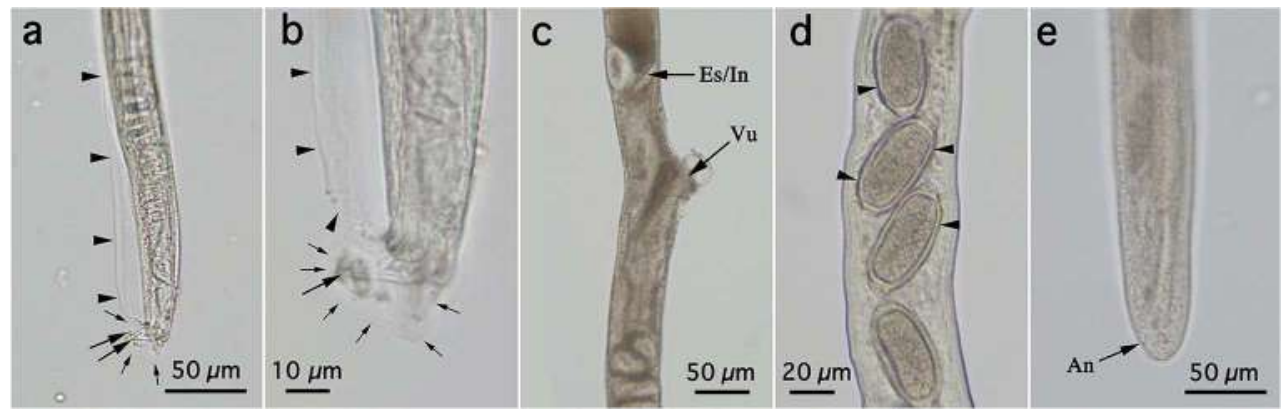

Fig. 3 Morphology of Aonchotheca bursata from Japanese green pheasants. a Left view of the caudal end of a male worm with left precloacal caudal alae (arrowheads) and membranous bursa (smaller arrows) supported by two digitate processes on left side (larger arrows). b A higher magnification of the caudal end of the male worm shown in a. See explanation of arrows and arrowheads in $\mathbf{a}$. At this magnification, only

of the vulva, and eggs with a finely granular surface. Measurements are shown in Table 4.

Remarks: According to Baruš and Sergejeva (1990b), five valid Aonchotheca species have been differentiated in birds from the Palaearctic region: A. bursata, A. caudinflata (Molin 1858) Moravec 1982, A. alpina (Boch et Forstner 1959) Freitas et Mendonca 1961, A. longifilla (Dujardin 1845) Baruš et Sergejeva 1990, and A. exilis (Dujardin 1845) Freitas et Mendonca 1961. Two of these species, A. bursata and $A$. caudinflata, are frequently isolated from the small intestine of domestic birds (chickens, turkeys, geese, guinea fowl, pigeons, and quails) in the absence of pathogenicity (Saif 2008). Among the five species described above, only these two have vulval appendages of different shapes (small one digitate process on left side is visible. c Semicircular transparent appendage around the opening of the vulva $(\mathrm{Vu})$, which lies posteriorly to the esophageal and intestinal border (Es/In). d Intrauterine eggs with finely granular surfaces (evident sites are indicated by arrowheads). e Caudal end of a female worm with a subterminal anus (An)

transparent semicircular versus conspicuous structures). The caudal ends of male worms collected in the current study were similar to that of A. bursata and distinct from that of A. caudinflata, in which the membranous bursa is supported by "T"'-shaped processes (Baruš and Sergejeva 1990b). Baruš and Sergejeva (1990b) divided the genus into two subgenera, Aonchotheca for species in mammalian hosts and Avesaonchotheca for species in avian hosts.

\section{Baruscapillaria obsignata (Madsen 1945) Moravec 1982}

This species was collected from the small intestines of various hosts, i.e., three (60\%) Japanese green pheasants, three (50\%) pigeons, three $(27.3 \%)$ geese, one $(6.3 \%)$ chicken, and one

Table 4 Measurements of Aonchotheca bursata from poultry at different localities

\begin{tabular}{|c|c|c|c|}
\hline Parasite species & A. bursata & A. bursata & A. caudinfin \\
\hline Host & Phasianus colchicus & Gallus gallus domestica & Gallus gallus domestica \\
\hline Location of nematodes & Small intestine & Small intestine & Small intestine \\
\hline Locality & Kumamoto, Japan & Russia & Czechoslovakia \\
\hline Reference & Present study & Baruš and Sergejeva (1990b) & Baruš and Sergejeva (1990b) \\
\hline Male & $(n=2)$ & $(n=7)$ & $(n=10)$ \\
\hline Body length & $15.66-17.71(16.69)$ & $14.8-16.0$ & $8.80-17.60$ \\
\hline Max. body width & $0.032-0.042(0.037)$ & $0.060-0.072$ & $0.041-0.059$ \\
\hline Esophagus length & $6.66-7.11(6.89)$ & $>4.9-5.2$ & $>3.4-6.3$ \\
\hline Length ratio of posterior body to anterior body & $1.35-1.49(1.42)$ & - & - \\
\hline Spicule length & $1.50-1.61(1.56)$ & $1.52-1.78$ & $0.71-1.25$ \\
\hline Female & $(n=5)$ & $(n=6)$ & $(n=10)$ \\
\hline Body length & $21.03-28.92(25.99 \pm 3.07)$ & $19.0-22.0$ & $11.88-25.38$ \\
\hline Max. body width & $0.052-0.071(0.063 \pm 0.008)$ & $0.060-0.068$ & $0.054-0.063$ \\
\hline Esophagus length & $6.65-8.02(7.44 \pm 0.62)$ & $>6.5-7.6$ & $>3.8-7.2$ \\
\hline Length ratio of posterior body to anterior body & $2.17-2.92(2.49 \pm 0.29)$ & - & - \\
\hline Distance from esophageal end to vulva & $0.045-0.127(0.087 \pm 0.036)$ & - & - \\
\hline Egg length & 0.051 & $0.052-0.055$ & $0.047-0.058$ \\
\hline Egg width & $0.024-0.030(0.026 \pm 0.003)$ & $0.020-0.022$ & $0.020-0.024$ \\
\hline
\end{tabular}


(100\%) turkey. The numbers of worms collected from pigeons were extremely high, with one pigeon having 131 worms (45 males and 86 females). Male worms without caudal alae had an unlobed pseudobursa supported by two small rounded lobes, narrower at the base, each with a tiny projection bent ventrally. Spicules were well sclerotized with bluntly rounded distal ends, and the surface of the spicular sheath was smooth but transversally wrinkled. Female worms had a vulva without any appendages near the midpoint of their body and a rounded posterior end with a subterminal anus. Bi-operculated symmetric eggs had smooth surfaces. Measurements are shown in Table 5.

Remarks: This species is the type species of the genus Baruscapillaria Moravec 1982. It has a wide host spectrum; all the avian hosts recorded here have previously been reported (Graybill 1924; Wakelin 1963, 1964, 1965; Tamaru et al. 2015). Tamaru et al. (2015) detected different morphometric values of $B$. obsignata from chickens and swans, including differences in the anterior and posterior body ratio of male and female worms as well as the spicule length of male worms. The specimens in the current study also displayed these differences, but were all genetically identified as B. obsignata based on their 18S rDNA nucleotide sequences (as discussed later).

\section{Capillaria anatis (Schrank 1790) Travassos 1915}

This species was collected from the ceca of three (18.8\%) chickens in Surabaya, Indonesia, although the number of collected worms was small (Table 2). Male worms had a caudal end with two massive ventrolateral lobes, but without a membranous bursa or caudal alae. Spicules were well sclerotized with bluntly rounded distal ends, and the spicular sheath had minute spines on its surface. Female worms had a vulva without any appendages at approximately the anterior $2 / 5$ of the body and a rounded posterior end with a subterminal anus. Bioperculated bent eggs, brown in color, had rugose surfaces. Measurements are shown in Table 6.

Remarks: This species is the type species of the genus Capillaria sensu stricto as redefined by Moravec (1982). Although this species has a wide host spectrum (including chickens, ducks, and geese) (Wakelin 1964, 1965) with worldwide distribution (Baruš and Sergejeva 1989a), only a few worms were collected in the current study. Thus, the active prevalence of this species in Indonesia should be determined in future work.

\section{Capillaria phasianina Kotlan 1940}

One male and four female worms were collected from the ceca of two (40\%) farmed Japanese green pheasants in Kumamoto, Japan. Because of specimen damage, only one worm of each sex was measured, although the other worms could be observed microscopically to determine their morphological features. The male worm had an enlarged caudal end with two massive ventrolateral lobes ending in one big papilla (Fig. 4). A wellsclerotized spicule was covered with a sheath densely armed with large triangular spines. Female worms had a vulva with tubular appendages at approximately the anterior $2 / 5$ of the body and a rounded posterior end with a terminal anus. Eggs had a finely rugose surface with protruded lids. Measurements are shown in Table 6 .

Remarks: Although only a few worms were microscopically observed, all of the aforementioned morphological features coincided well with those of Capillaria phasianina (Baruš and Sergejeva 1989a). This species has a cosmopolitan distribution and has been recorded from chickens, Indian peafowls, pheasants, partridges, snowcocks, guinea fowl, and turkeys (Kellogg and Prestwood 1968; Baruš and Sergejeva 1989a).

\section{Capillaria spinulosa (Linstow 1890) Travassos 1915}

One of six (16.7\%) ducks and three of $11(27.3 \%)$ geese were found to have this species in their ceca, with one to six worms per host; eight males and five females were collected in total. Because of the extent of specimen damage, only a few worms could be measured, although the other worms were observed microscopically to check critical morphological features. Male worms had a caudal end with two ventrolateral lobes (Fig. 5). Two small papillae were observed at the anteroventral edge of each lobe, around the level of the cloaca. A wellsclerotized spicule was covered with a sheath densely armed with distinct spines. Female worms had a vulva without appendages at approximately the anterior $2 / 5$ of the body and a rounded posterior end with a terminal anus. Bi-operculated eggs had an almost smooth surface and the protrusion of lids was slight. Measurements are shown in Table 7.

Remarks: According to Baruš and Sergejeva (1989a), only nine valid Capillaria species are distributed in birds of the Palaearctic region, including Capillaris phasianina and Capillaria anatis mentioned above. However, Capillaria pudendotecta Lubimova 1947, isolated from the ceca of swans, should also be included in this list of valid species with a Palaearctic distribution because Tamaru et al. (2015) recorded the caudal morphology of male worms, which was unknown at that time, and classified the species in the genus Capillaria sensu stricto. All the morphological features of the current specimens coincide well with those of Capillaria spinulosa recorded from Anseriformes, such as swans and wild ducks (Baruš and Sergejeva 1989a). One exception is the location of the anus in female worms, which was terminal in the current specimens versus subterminal in the description of the species by Baruš and Sergejeva (1989a). 
Table 5 Measurements of Baruscapillaria obsignata from poultry at different localities

\begin{tabular}{|c|c|c|c|c|c|}
\hline $\begin{array}{l}\text { Host } \\
\text { Location of nematodes } \\
\text { Locality } \\
\text { Reference }\end{array}$ & $\begin{array}{l}\text { Pheasant } \\
\text { Small intestine } \\
\text { Kumamoto, Japan } \\
\text { Present study }\end{array}$ & $\begin{array}{l}\text { Pigeon } \\
\text { Small intestine } \\
\text { Surabaya, Indonesia } \\
\text { Present study }\end{array}$ & $\begin{array}{l}\text { Goose } \\
\text { Small intestine } \\
\text { Surabaya, Indonesia } \\
\text { Present study }\end{array}$ & $\begin{array}{l}\text { Turkey } \\
\text { Small intestine } \\
\text { Surabaya, Indonesia } \\
\text { Present study }\end{array}$ & $\begin{array}{l}\text { Chicken } \\
\text { Small intestine } \\
\text { Kagoshima, Japan } \\
\text { Tamaru et al. (2015) }\end{array}$ \\
\hline Male & $(n=4)$ & $(n=6)$ & $(n=4)$ & $(n=6)$ & $(n=22)$ \\
\hline Body length & $7.61-8.60(8.15 \pm 0.51)$ & $8.58-11.00(9.76 \pm 0.89)$ & $7.23-9.67(8.44 \pm 1.19)$ & $8.95-10.50(9.92 \pm 0.60)$ & $5.31-10.61(7.67 \pm 0.99)$ \\
\hline Max. body width & $0.035-0.039(0.038 \pm 0.002)$ & $0.040-0.059(0.050 \pm 0.008)$ & $0.041-0.045(0.044 \pm 0.002)$ & $0.041-0.067(0.049 \pm 0.010)$ & $0.028-0.056(0.046 \pm 0.007)$ \\
\hline Esophagus length & $4.10-4.97(4.54 \pm 0.36)$ & $3.96-5.24(4.77 \pm 0.53)$ & $4.48-5.15(4.80 \pm 0.33)$ & $4.65-5.27(4.93 \pm 0.28)$ & $3.61-6.61(4.77 \pm 0.60)$ \\
\hline $\begin{array}{l}\text { Length ratio of posterior } \\
\text { body to anterior body }\end{array}$ & $0.57-0.91(0.80 \pm 0.16)$ & $0.87-1.30(1.06 \pm 0.16)$ & $0.59-0.88(0.75 \pm 0.14)$ & $0.87-1.15(1.01 \pm 0.11)$ & $0.44-0.78(0.61 \pm 0.08)$ \\
\hline Spicule length & $1.05-1.18(1.11 \pm 0.07)$ & $1.25-1.77(1.53 \pm 0.18)$ & $1.04-1.36(1.19 \pm 0.16)$ & $1.19-1.32(1.26 \pm 0.06)$ & $0.87-1.26(0.99 \pm 0.08)$ \\
\hline Female & $(n=3)$ & $(n=6)$ & $(n=9)$ & $(n=6)$ & $(n=7)$ \\
\hline Body length & $9.02-16.84(11.70 \pm 4.45)$ & $12.67-16.28(14.53 \pm 1.39)$ & $8.00-12.30(10.34 \pm 1.88)$ & $12.69-14.65(13.49 \pm 0.79)$ & $6.19-10.56(8.80 \pm 1.62)$ \\
\hline Max. body width & $0.052-0.065(0.060 \pm 0.007)$ & $0.066-0.076(0.071 \pm 0.005)$ & $0.049-0.072(0.062 \pm 0.008)$ & $0.053-0.075(0.059 \pm 0.008)$ & $0.052-0.064(0.058 \pm 0.005)$ \\
\hline Esophagus length & $4.53-5.71(5.00 \pm 0.63)$ & $5.22-6.95(6.12 \pm 0.57)$ & $4.21-6.20(5.14 \pm 0.72)$ & $5.19-6.31(5.58 \pm 0.67)$ & $3.94-5.64(4.87 \pm 0.69)$ \\
\hline $\begin{array}{l}\text { Length ratio of posterior } \\
\text { body to anterior body }\end{array}$ & $0.89-1.95(1.30 \pm 0.57)$ & $1.28-1.54(1.38 \pm 0.10)$ & $0.77-1.48(1.01 \pm 0.21)$ & $1.00-1.63(1.31 \pm 0.22)$ & $0.57-0.87(0.80 \pm 0.10)$ \\
\hline $\begin{array}{l}\text { Distance from esophageal } \\
\text { end to vulva }\end{array}$ & $0.035-0.076(0.062 \pm 0.023)$ & $0-0.110(0.064 \pm 0.042)$ & $0.047-0.094(0.074 \pm 0.013)$ & $0.076-0.150(0.112 \pm 0.034)$ & $0.039-0.072(0.060 \pm 0.011)$ \\
\hline Egg length & 0.048 & $0.045-0.049(0.047 \pm 0.002)$ & $0.041-0.049(0.044 \pm 0.002)$ & $0.042-0.054(0.049 \pm 0.004)$ & $0.048-0.059(0.053 \pm 0.004)$ \\
\hline Egg width & 0.026 & $0.023-0.028(0.025 \pm 0.002)$ & $0.023-0.029(0.025 \pm 0.002)$ & $0.025-0.030(0.028 \pm 0.002)$ & $0.024-0.031(0.027 \pm 0.002)$ \\
\hline
\end{tabular}


Table 6 Measurements of Capillaria anatis from chickens at different localities, and Capillaria phasianina from pheasants

\begin{tabular}{|c|c|c|c|c|c|c|}
\hline Parasite species & C. anatis & C. anatis & C. anatis & C. anatis & C. phasianina & C. phasianina \\
\hline Host & Chicken & Chicken & Chicken & Chicken & Phasianus colchicus versicolor & $\begin{array}{l}\text { Phasianus colchicus, } \\
\text { Perdix perdix, Pavo cristatis }\end{array}$ \\
\hline Location of nematodes & Cecum & Cecum & Cecum & Cecum & Cecum & Cecum \\
\hline Locality & Surabaya, Indonesia & Kagoshima, Japan & $\begin{array}{l}\text { Davao Oriental, } \\
\text { Philippines }\end{array}$ & U.K. & Kumamoto, Japan & Russia \\
\hline Reference & Present study & Tamaru et al. (2015) & Tamaru et al. (2015) & Wakelin (1964) & Present study & $\begin{array}{l}\text { Baruš and Sergejeva } \\
\text { (1989a) }\end{array}$ \\
\hline Male & $(n=3)$ & $(n=28)$ & $(n=21)$ & $(n=100)$ & $(n=1)$ & $(n=7)$ \\
\hline Body length & $10.95-13.97(12.15 \pm 1.60)$ & $6.42-9.97(8.64 \pm 1.03)$ & $7.69-14.06(12.35 \pm 1.36)$ & $6.70-13.14(10.29)$ & 19.29 & $14.7-19.0$ \\
\hline Max. body width & $0.053-0.065(0.059 \pm 0.006)$ & $0.036-0.064(0.049 \pm 0.007)$ & $0.050-0.072(0.064 \pm 0.006)$ & $0.035-0.058$ & 0.065 & $0.045-0.050$ \\
\hline Esophagus length & $4.76-5.77(5.29 \pm 0.51)$ & $3.44-5.06(4.30 \pm 0.48)$ & $3.50-6.69(5.69 \pm 0.67)$ & $4.23-5.29$ & 5.48 & $>5.6-6.7$ \\
\hline $\begin{array}{l}\text { Length ratio of posterior } \\
\text { body to anterior body }\end{array}$ & $1.06-1.42(1.30 \pm 0.21)$ & $0.82-1.29(1.01 \pm 0.12)$ & $1.02-1.41(1.17 \pm 0.12)$ & - & 2.52 & - \\
\hline Spicule length & $0.94-1.15(1.05 \pm 0.11)$ & $0.73-1.21(1.00 \pm 0.11)$ & $0.89-1.12(1.01 \pm 0.07)$ & $1.06-1.86(1.46[n=40])$ & 2.55 & $1.55-2.40$ \\
\hline Female & $(n=2)$ & $(n=29)$ & $(n=18)$ & $(n=100)$ & $(n=1)$ & $(n=8)$ \\
\hline Body length & $13.56-14.23(13.90)$ & $7.25-16.58(11.98 \pm 1.97)$ & $12.61-20.83(17.39 \pm 2.52)$ & $8.11-18.34(14.62)$ & 19.77 & $22-28$ \\
\hline Max. body width & $0.055-0.058(0.056)$ & $0.050-0.080(0.065 \pm 0.009)$ & $0.060-0.106(0.086 \pm 0.013)$ & $0.044-0.060$ & 0.065 & $0.065-0.084$ \\
\hline Esophagus length & $5.24-5.48(5.36)$ & $3.00-6.56(4.83 \pm 0.65)$ & $4.97-6.94(6.23 \pm 0.52)$ & $4.23-6.70$ & 5.44 & $>6.6-8.7$ \\
\hline $\begin{array}{l}\text { Length ratio of posterior } \\
\text { body to anterior body }\end{array}$ & 1.59 & $1.09-1.88(1.48 \pm 0.18)$ & $1.37-2.13(1.78 \pm 0.23)$ & ca. 2 & 2.64 & - \\
\hline $\begin{array}{l}\text { Distance from oesophageal } \\
\text { end to vulva }\end{array}$ & $0.023-0.068(0.045)$ & $0.011-0.083(0.042 \pm 0.017)$ & $0.011-0.117(0.040 \pm 0.024)$ & - & - & - \\
\hline Egg length & $0.054-0.059(0.057 \pm 0.002)$ & $0.053-0.063(0.059 \pm 0.003)$ & $0.049-0.066(0.059 \pm 0.004)$ & $0.055-0.062(0.058)$ & $0.041-0.049(0.046 \pm 0.004)$ & $0.052-0.057$ \\
\hline Egg width & $0.024-0.029(0.027 \pm 0.001)$ & $0.024-0.034(0.029 \pm 0.002)$ & $0.026-0.037(0.029 \pm 0.003)$ & $0.022-0.029(0.027)$ & $0.024-0.025(0.025 \pm 0.001)$ & $0.025-0.027$ \\
\hline
\end{tabular}




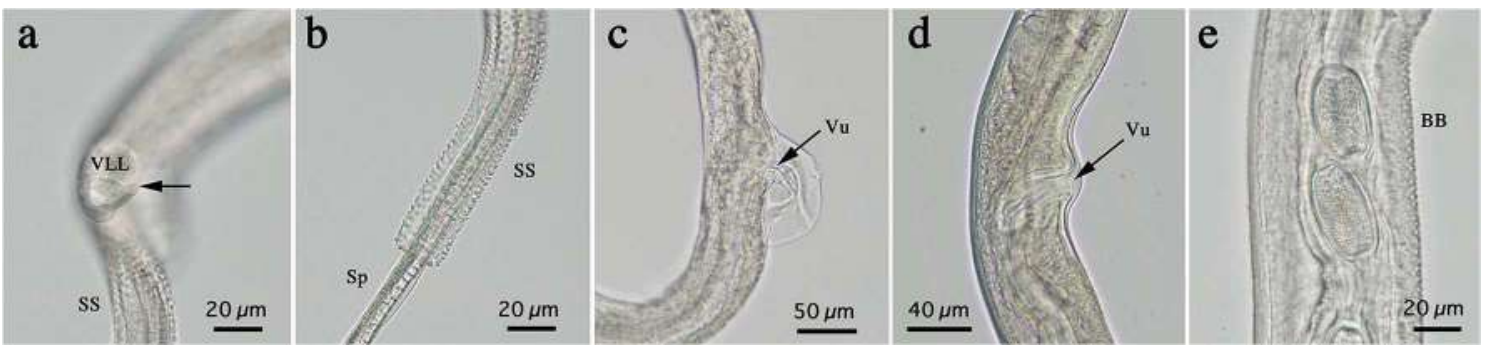

Fig. 4 Morphology of Capillaria phasianina from Japanese green pheasants. a Right view of the caudal end of a male worm with two massive ventrolateral lobes (in this photograph, only the right lobe (VLL) is visible laterally), which end in one big papilla (arrow). SS indicates protruded spicular sheath from the cloaca. b Protruded spicular sheath densely armed with spines (SS) and spicule (Sp). c Tubular vulval

\section{Phylogenetic analysis}

Nucleotide sequences of the $18 \mathrm{~S}$ rDNA were successfully obtained for six of the seven Capillariidae species examined here. For three worms of E. perforans from Japanese green pheasants, two types of 1798-bp-long sequences were obtained. The nucleotide identity between these two sequences was $99.72 \%$ (1793/1798). For two worms of E. contortus from different goose individuals, absolutely identical 1798-bplong sequences were obtained. The nucleotide identities between E. perforans and E. contortus were $97.22 \%$ $(1747 / 1797)$ to $97.27 \%(1748 / 1797)$ with two indels. Among several Eucoleus spp. with deposited nucleotide sequences in the DDBJ/EMBL/GenBank databases, E. dispar from German Buteo lagopus (accession no. EU004821; 1767 bp) was the only one from an avian host. The nucleotide identities of the newly obtained E. perforans and E. contortus $18 \mathrm{~S}$ rDNA nucleotide sequences ranged from $96.75 \%$ (1698/1755) to $97.78 \%$ (1716/1755) with 12 indels. More than a half of the interspecific variations (56.36$57.69 \%$ ) were localized in the first third of the entire $18 \mathrm{~S}$ rDNA nucleotide sequences, followed by the final third (25.00-28.21\%) and then the middle third (15.38-18.18\%).

Among several Aonchotheca spp. with deposited nucleotide sequences in the DDBJ/EMBL/GenBank databases, appendage of a female worm (in this case, it bent upon attachment to the cuticular surface). d Vulval appendage still inverted in the vaginal space, suggesting that this female worm might have never produced eggs. $\mathrm{Vu}$ in $\mathbf{c}$ and $\mathbf{d}$ indicates vulval opening. e Intrauterine eggs with finely rugose surfaces (not evident in this photograph). The bacillary band on the cuticular surface is evident in one side (BB)

A. bursata from a Japanese green pheasant was closest to A. putorii from the small intestine of martens, badgers, feral cats, feral raccoons, and hedgehogs (accession nos. LC052349-LC052363) with $97.63 \%$ (1769/1812) to $97.90 \%$ (1775/1813) nucleotide identities and 35-37 indels. Since no nucleotide sequences of Aonchotheca spp. from birds were available in the databases, we could not compare our isolate with any Aonchotheca isolates from avian hosts.

Nucleotide sequences of $B$. obsignata from the small intestine of pigeons in Indonesia were absolutely identical to those of B. obsignata from chickens (100\% [1812/1812]) and captive swans (100\% [1693/1693]) in Japan.

Two isolates of Capillaria spinulosa from the ceca of a duck and goose had identical 18S rDNA nucleotide sequences. Among Capillaria spp. with deposited 18S rDNA nucleotide sequences (including Capillaria anatis, Capillaria madseni, Capillaria pudendotecta, and Capillaria tenuissima (Rudolphi 1803) Travassos 1915), the highest nucleotide identity with our Capillaria spinulosa isolates was Capillaria pudendotecta in the ceca of captive swans in Japan (97.14\% [1768/1820] with 14 indels; accession no. LC052339). Two isolates of Capillaria anatis from the ceca of chickens had identical 18S rDNA nucleotide sequences. The highest nucleotide identities were with Japanese isolates from chickens (99.89\% [1818/1820]; accession no.

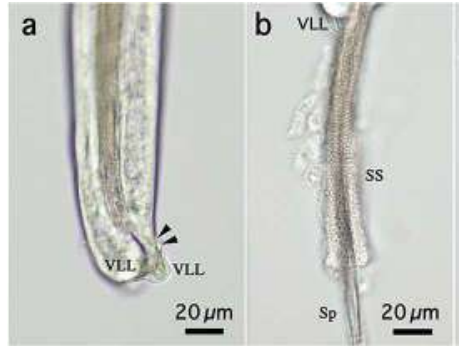

Fig. 5 Morphology of Capillaria spinulosa from domestic geese and ducks. a Ventrolateral view of the caudal end of a male worm with two ventrolateral lobes (VLL), each lobe having two small papillae (arrowheads) at the anteroventral edge, around the level of the cloaca. b
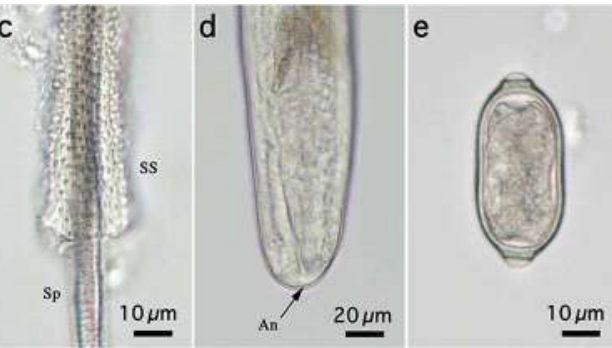

Well-sclerotized spicule $(\mathrm{Sp})$ covered with a sheath densely armed with distinct spines (SS). $\mathbf{c}$ A higher magnification of the spicule and sheath shown in b. d Rounded posterior end of a female worm with a terminal anus (An). e Bi-operculated egg with a smooth surface 
Table 7 Measurements of Capillaria spinulosa from geese and ducks, with comparison with those of Capillaria pudendotecta from swans and Capillaria anatis in chickens

\begin{tabular}{|c|c|c|c|c|c|c|}
\hline Parasite species & C. spinulosa & C. spinulosa & C. spinulosa & C. spinulosa $a^{a}$ & C. pudendotecta & C. anatis \\
\hline Host & $\begin{array}{l}\text { Anas platyrhynchos var. } \\
\text { domesticus }\end{array}$ & $\begin{array}{l}\text { Anser cygnoides } \\
\text { domesticus }\end{array}$ & $\begin{array}{l}\text { Aythya fuligula, Aythya } \\
\text { marila, Netta rufina }\end{array}$ & Cygnus olor & Cygnus olor & Chicken \\
\hline Location of nematodes & Cecum & Cecum & Cecum & Cecum & Cecum & Cecum \\
\hline Locality & Surabaya, Indonesia & Surabaya, Indonesia & Russia & Kirghizia, USSR & Yamaguchi, Japan & Surabaya, Indonesia \\
\hline Reference & Present study & Present study & $\begin{array}{l}\text { Baruš and Sergejeva } \\
\text { (1989a) }\end{array}$ & $\begin{array}{l}\text { Skrjabin et al. } \\
\text { (1957) }\end{array}$ & Tamaru et al. (2015) & Present study \\
\hline Male & $(n=3)$ & $(n=3)$ & $(n=13)$ & $(n=?)$ & $(n=12)$ & $(n=3)$ \\
\hline Body length & $15.00-16.71(15.29 \pm 1.30)$ & $\begin{array}{l}12.34-14.58(13.19 \pm \\
1.21)\end{array}$ & $8.30-9.36$ & 12.5 & $\begin{array}{l}11.81-17.53(15.28 \pm \\
1.89)\end{array}$ & $\begin{array}{l}10.95-13.97(12.15 \pm \\
1.60)\end{array}$ \\
\hline Max. body width & $0.055-0.057(0.056 \pm 0.010)$ & $\begin{array}{l}0.038-0.052(0.045 \pm \\
\quad 0.007)\end{array}$ & $0.030-0.036$ & 0.108 & $\begin{array}{l}0.052-0.084(0.069 \pm \\
0.010)\end{array}$ & $\begin{array}{l}0.053-0.065(0.059 \pm \\
\quad 0.006)\end{array}$ \\
\hline Esophagus length & $5.88-6.74(6.29 \pm 0.43)$ & $5.27-5.84(5.47 \pm 0.32)$ & $>3.64-4.20$ & - & $6.58-10.08(8.71 \pm 1.13)$ & $4.76-5.77(5.29 \pm 0.51)$ \\
\hline $\begin{array}{l}\text { Length ratio of posterior } \\
\text { body } \\
\text { to anterior body }\end{array}$ & $1.26-1.55(1.43 \pm 0.15)$ & $1.34-1.50(1.41 \pm 0.08)$ & - & - & $0.65-0.89(0.76 \pm 0.08)$ & $1.06-1.42(1.30 \pm 0.21)$ \\
\hline Spicule length & $0.65-0.72(0.69 \pm 0.04)$ & $0.74-0.78(0.76 \pm 0.02)$ & $0.60-0.80$ & 0.58 & $0.70-0.93(0.79 \pm 0.07)$ & $0.94-1.15(1.05 \pm 0.11)$ \\
\hline Body length & $15.00-16.71(15.29 \pm 1.30)$ & $\begin{array}{l}12.34-14.58(13.19 \pm \\
1.21)\end{array}$ & $8.30-9.36$ & 12.5 & $\begin{array}{l}11.81-17.53(15.28 \pm \\
1.89)\end{array}$ & $\begin{array}{l}10.95-13.97(12.15 \pm \\
1.60)\end{array}$ \\
\hline Female & $(n=1)$ & $(n=3)$ & $(n=9)$ & $(n=?)$ & $(n=14)$ & $(n=2)$ \\
\hline Body length & 24.4 & $\begin{array}{l}10.06-23.61(16.80 \pm \\
6.77)\end{array}$ & $11.0-18.5$ & - & $\begin{array}{l}18.16-26.27(22.76 \pm \\
2.07)\end{array}$ & $13.25,14.23(13.74)$ \\
\hline Max. body width & 0.071 & $\begin{array}{l}0.052-0.073(0.060 \pm \\
0.012)\end{array}$ & $0.050-0.056$ & 0.077 & $\begin{array}{l}0.068-0.102(0.081 \pm \\
0.009)\end{array}$ & $0.055,0.058(0.057)$ \\
\hline Esophagus length & 6.65 & $5.18-7.89(6.32 \pm 1.40)$ & $>4.7-7.5$ & - & $7.56-10.52(10.12 \pm 1.00)$ & $5.24,5.48(5.36)$ \\
\hline $\begin{array}{l}\text { Length ratio of posterior } \\
\text { body } \\
\text { to anterior body }\end{array}$ & 2.67 & $0.94-1.99(1.59 \pm 0.57)$ & - & - & $1.23-1.57(1.40 \pm 0.09)$ & 1.59 \\
\hline $\begin{array}{l}\text { Distance from oesophageal } \\
\text { end to vulva }\end{array}$ & - & $\begin{array}{l}0.058-0.427(0.186 \pm \\
0.208)\end{array}$ & - & - & $\begin{array}{l}0.030-0.167(0.072 \pm \\
0.042)\end{array}$ & $0.023,0.068(0.046)$ \\
\hline Egg length & 0.045 & $\begin{array}{l}0.040-0.050(0.046 \pm \\
0.06)\end{array}$ & - & 0.045 & $\begin{array}{l}0.042-0.052(0.046 \pm \\
0.002)\end{array}$ & $\begin{array}{l}0.054-0.059(0.057 \pm \\
0.002)\end{array}$ \\
\hline Egg width & 0.024 & $\begin{array}{l}0.021-0.024(0.022 \pm \\
0.002)\end{array}$ & - & 0.024 & $\begin{array}{l}0.021-0.026(0.024 \pm \\
0.001)\end{array}$ & $\begin{array}{l}0.024-0.029(0.027 \pm \\
0.001)\end{array}$ \\
\hline
\end{tabular}


LC052334) and Philippine isolates from chickens (99.62\% [1813/1820]; accession no. LC052335).

An ML phylogenetic tree based on the 18S rDNA nucleotide sequences of representative species of the family Capillariidae is shown in Fig. 6. All species shown in the figure clustered robustly according to the genera redefined by Moravec (1982), regardless of host preference, i.e., birds or mammals.

\section{Discussion}

According to our current findings, the phylogenetic tree based on nucleotide sequences of 18S rDNA from members of the family Capillariidae supported the accuracy of Moravec's taxonomic system because all the included species clustered robustly according to his redefinition of the genera (Moravec 1982). One minor exception is a clade of Aonchotheca, which included not only Aonchotheca spp. but also Pearsonema spp. and Pseudocapillaria tomentosa. This point, therefore, requires further investigation in the future. The morphological features of the male caudal end used for separation of genera of the family include the presence or absence and characteristics of caudal lobes, papillae, dorsal cuticular membrane, and caudal alae; the characteristics of the spicular sheath (spinous or non-spinous); and the presence or absence of a spicule (Moravec 1982). According to these morphological criteria, we divided the specimens collected from poultry in Japan and Indonesia into four genera, i.e., Eucoleus, Aonchotheca, Baruscapillaria, and Capillaria, and identified seven species based on other morphological features of male and female worms.

By evaluating the 18S rDNA of capillariid species (less than $620 \mathrm{bp}$ in length and situated near the 3 '-terminus), Guardone et al. (2013) concluded that this gene was highly conserved among different species and showed very low interspecific variation. However, when almost whole lengths of the $18 \mathrm{~S}$ rDNA of several capillariid species were sequenced and compared in this study, we found that three-quarters of interspecific variations, including indels, were localized in the anterior half of the gene. Since base positions of indels of any species or isolate(s) are omitted, and only nucleotide substitutions in the remaining base positions are used for the construction of a phylogenetic tree, the phylogenetic distances between different species in the tree are often underestimated. Nevertheless, even under such conditions, the species of different genera, i.e., those of Eucoleus, Baruscapillaria, Aonchotheca, and Capillaria, were well separated in different clades in the phylogenetic tree based on the 18S rDNA nucleotide sequences. Therefore, $18 \mathrm{~S}$ rDNA nucleotide sequences, particularly long ones, may be highly useful for the generic and specific identification of capillariid worms in instances when morphological speciation is impossible owing to worm damage or poor morphology. However, based on Baruš and Sergejeva's work (1989a, b, 1990a, b) reporting that at least nine Capillaria spp., five Eucoleus spp., one Echinocoleus sp., nine Baruscapillaria spp., four Pterothominx spp., and five Aonchotheca spp. are parasitic in birds of the Palaearctic region, the possibility of generic and specific identification of specimens collected during daily activities is quite low. Thus, increased efforts to collect and genetically characterize more species of this taxonomic group are necessary to facilitate the specific identification of capillariid worms.

In a previous study from our laboratory (Tamaru et al. 2015), we revealed a spectrum of morphometric variations of genetically specified species, e.g., Capillaria anatis isolated from chickens in Japan and the Philippines. Although male Capillaria anatis worms isolated from chickens in Indonesia appeared to have morphometric features similar to male worms isolated from Philippine chickens, the 18S rDNA nucleotide sequence was apparently identical to that of the isolates from Japanese chickens, suggesting that the morphometric variations cannot be ascribed to genetic backgrounds but to other factors, such as different physiological or immunological conditions. Although Capillaria spinulosa cannot be easily morphologically discriminated from Capillaria pudendotecta or Capillaria anatis owing to variations in several morphometric values and vulval appendages, the genetic characterization of these three species clearly differentiated them from one another. In this regard, morphological examination of capillariid worms together with molecular genetic analysis is highly recommended until the geographical distribution and host ranges of multiple Capillariidae species are known.

Fatal infection by Eucoleus spp. in the upper digestive tract (originally crops and extending to the upper esophagus and mouth) is a major problem in guinea fowls, turkeys, partridges, pheasants, and quails (Bickford and Gaafar 1966; Itagaki 1966; Itagaki et al. 1974; De Rosa and Shivapprasad 1999; Cruz et al. 2016). Clinically, droopiness, weakness, anorexia, vomiting, and emaciation are observed owing to local necrosis and severe inflammation (mucosal coverage of flocculent exudates, thickening, and sloughing) caused by heavy infection of mucosa-perforating Eucoleus spp. and dysfunction of the esophagus. It appears that the causative thin filiform nematodes of Capillariidae tend to be diagnosed as "E. contortus" sensu lato (including E. annulatus and $E$. perforans) without any detailed morphological observations because of historical taxonomic complications and difficulties in differentiating Eucoleus spp. (Madsen 1951; Bickford and Gaafar 1966; De Rosa and Shivapprasad 1999). Actually, in the current study, the most evident morphological feature that could be used to separate E. perforans and E. contortus was eggshell surface, 


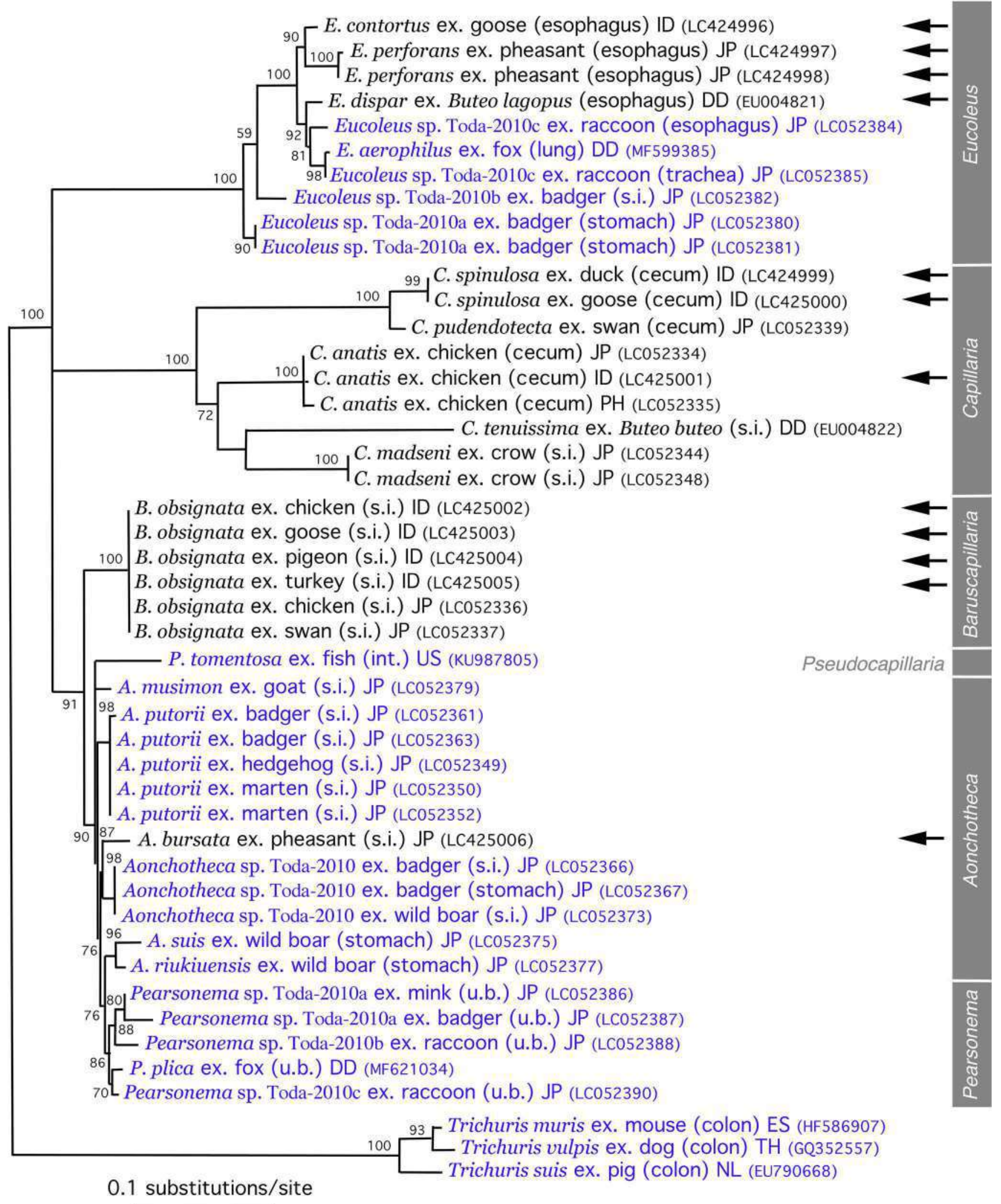

Fig. 6 ML phylogenetic tree based on the 18S rDNA sequence. The name of the species followed by the host, isolation organ, country where the worm was collected, and accession number in parentheses are given for each isolate. DD, Germany; ES, Spain; ID, Indonesia; int., intestine; JP, Japan; NL, Netherlands; PH, Philippines; s.i., small intestine; TH, Thailand; u.b., urinary bladder; US, United States of America. Black-colored sequences signify species from avian hosts and blue-colored sequences denote species from mammalian hosts. Newly obtained sequences in the present study are indicated by arrows 
and the molecular genetic analyses supported the morphological separation of these two species. Severe capillariasis of crops in game-farm pheasants (Phasianus colchicus) has been reported in North America and routinely ascribed to $E$. contortus without careful morphological observation. It is possible that all Eucoleus spp. could be pathogenic, and molecular characterization of the 18S rDNA of isolated worms could facilitate specific diagnosis hereafter because three Eucoleus spp. dwelling in the esophageal mucosa have been genetically characterized in a previous study (Honisch and Krone 2008) and the current study. E. annulatus, another important species in poultry, exhibits cephalic swelling as one of only a few morphological features (Baruš and Sergejeva 1989b) and has not yet been characterized at the molecular genetic level; this should be an objective for future work. This species requires earthworms as an intermediate host, whereas $E$. perforans and E. contortus employ the direct life cycle without intermediate hosts (Cram 1936; Wehr 1936; Zucchero 1942).

The molecular genetic characterization of $B$. obsignata and Capillaria anatis from Indonesian poultry demonstrated the lowest nucleotide variation of $18 \mathrm{~S}$ rDNA sequences, with no or only few nucleotide variations, respectively, between these newly collected Indonesian isolates and Japanese isolates reported previously (Tamaru et al. 2015). In the case of E. perforans, however, isolates from farmed Japanese green pheasants at the same locality showed five nucleotide substitutions over the 1798-bp-long 18S rDNA. Therefore, it is important to note that even the stable $18 \mathrm{~S}$ rDNA nucleotide sequences of capillariid worms from domesticated birds, i.e., poultry, can have a certain degree of nucleotide variations. Consequently, the extent of genetic variation in species, e.g., that in Eucoleus aerophilus and Eucoleus boehmi in domestic and wild canids (Di Cesare et al. 2014, 2015), requires further investigation.

To date, $18 \mathrm{~S}$ rDNA nucleotide sequences have been deposited for 10 species of Capillariidae in birds, including four species from wild birds (E. dispar, Capillaria tenuissima, Capillaria madseni, and Capillaria pudendotecta) and six species from poultry. Although difficulties in the morphological differentiation of species or taxonomic complications of described species have hindered the accumulation of deposited DNA sequences, increasing our understanding of the molecular genetics of thin filiform nematodes will undoubtedly facilitate the daily diagnoses of the causes of diseases in poultry. Comprehension of the real biodiversity and assessment of the accuracy of the current taxonomic system (recorded species divided into 27 genera) (Gibbons 2010)) can be simultaneously achieved by the molecular genetic characterization of collected worms by researchers worldwide who study fine nematodes with taxonomic complications (Zhu et al. 2000; Di Cesare et al. 2014, 2015; Feldman and Ramirez 2014; Varcasia et al. 2015; Fantozzi et al. 2018).
Acknowledgment We thank Professor Emeritus Shuhei Tanaka (Faculty of Agriculture, Yamaguchi University) for assistance with the SEM analysis.

Funding information We also thank the Faculty of Veterinary Medicine, Airlangga University, for supporting the international collaborative study with the Joint Faculty of Veterinary Medicine, Yamaguchi University.

\section{Compliance with ethical standards}

The ethics of animal processing and sample collection adhered to in this study followed the guidelines outlined in the veterinary section of the Kumamoto Prefecture for Municipal Routine Survey and Faculty of Veterinary Medicine, Airlangga University for Veterinary Professional Education and Research (Ethical Clearance No. 1.KE.047.04.2019).

Conflicts of interest The authors declare that they have no conflicts of interest.

\section{References}

Anderson RC (1992) Nematode parasites of vertebrates: their development and transmission. CAB International, Oxon, p 578

Anisimova M, Gascuel O (2006) Approximate likelihood-ratio test for branches: a fast, accurate, and powerful alternative. Syst Biol 55: 539-552

Baruš V, Sergejeva TP (1989a) Capillariids parasitic in birds in the Palaearctic region (1): Genus Capillaria. Acta Sci Nat Brno 23(3): $1-50$

Baruš V, Sergejeva TP (1989b) Capillariids parasitic in birds in the Palaearctic region (2): Genera Eucoleus and Echinocoleus. Acta Sci Nat Brno 23(6):1-47

Baruš V, Sergejeva TP (1990a) Capillariids parasitic in birds in the Palaearctic region (3): Genus Baruscapillaria. Acta Sci Nat Brno 24(10): $1-53$

Baruš V, Sergejeva TP (1990b) Capillariids parasitic in birds in the Palaearctic region (4): Genera Pterothominx and Aonchotheca. Acta Sci Nat Brno 24(12):1-48

Bickford AA, Gaafar SM (1966) Multiple capillariasis in game-farm pheasants. Avian Dis 10:428-437

Cram EB (1936) Species of Capillaria in the upper digestive tract of birds. Tech Bull U S Dept Agric 516:1-27

Cruz CEF, Fredo G, Casagrande R, Oliveira L, Rolim V, Marques S, Pavarini S, Driemeier D (2016) Eucoleus contortus parasitism in captive-bred valley quail Callipepla californica (Shaw, 1798): Disease and control. Zool Gart 85:152-159

De Rosa M, Shivapprasad HL (1999) Case report: capillariasis in a vulture guinea fowl. Avian Dis 43:131-135

Dereeper A, Guignon V, Blanc G, Audic S, Buffet S, Chevenet F, Dufayard JF, Guindon S, Lefort V, Lescot M, Claverie JM, Gascuel O (2008) Phylogeny.fr: robust phylogenetic analysis for the non-specialist. Nucleic Acids Res 36:465-469

Di Cesare A, Otranto D, Latrofa MS, Veronesi F, Perrucci S, Lalosevic D, Gherman CM, Traversa D (2014) Genetic variability of Eucoleus aerophilus from domestic and wild hosts. Res Vet Sci 96:512-515

Di Cesare A, Veronesi F, di Regalbono AF, De Liberato C, Perrucci S, Iorio R, Morganti G, Marangi M, Simonato G, Traversa D (2015) PCR-based assay for the mitochondrial cox1 specific amplification of Eucoleus böhmi. Vet Parasitol 211:67-70

Fantozzi MC, Robles MR, Peña FE, Antoniazzi LR, Beldomenico PM, Monje LD (2018) Calodium hepaticum (Nematoda: Capillariidae) in wild rodent populations from Argentina. Parasitol Res 117:29212926 
Feldman SH, Ramirez M (2014) Molecular phylogeny of Pseudocapillaroides xenopi (Moravec et Cosgrov 1982) and development of a quantitative PCR assay for its detection in aquarium sediment. J Am Assoc Lab Anim Sci 53:668-674

Gibbons LM (2010) Keys to the nematode parasites of vertebrates. Supplementary volume. CAB International, Oxon, p 416

Graybill HW (1924) Capillaria columbae (Rud.) from the chicken and turkey. J Parasitol 10:205-207

Guardone L, Deplazes P, Macchioni F, Magi M, Mathis A (2013) Ribosomal and mitochondrial DNA analysis of Trichuridae nematodes of carnivores and small mammals. Vet Parasitol 197:364-369

Guindon S, Gascuel O (2003) A simple, fast, and accurate algorithm to estimate large phylogenies by maximum likelihood. Syst Biol 52: 696-704

Hodda M (2011) Phylum Nematoda Cobb 1932. In: Zhang ZQ (ed) Animal biodiversity: an outline of higher-level classification and survey of taxonomic richness, pp 63-95. Zootaxa 3148 (Monograph)

Honisch M, Krone O (2008) Phylogenetic relationships of Spiruromorpha from birds of prey based on $18 \mathrm{~S}$ rDNA. J Helminthol 82:129-133

Itagaki H (1966) Studies on Capillaria sp. from the upper digestive tract of the guinea fowl. I. Morphology and development. Jpne Jf Parasitol 15:368-370 (in Japanese)

Itagaki H, Watanabe T, Kobara J (1974) Studies on Capillaria perforans Kotlán et Orosz, 1931 from the guinea fowl I. Morphology. Bull Azabu Vet Coll 28:77-82 (in Japanese)

Kellogg FE, Prestwood AK (1968) Case report and differentiating characteristics of Capillaria phasianina from pen-raised pheasants of Maryland. Avian Dis 12:518-522

Madsen H (1951) Note on the species of Capillaria Zeder, 1800 known from gallinaceous birds. J Parasitol 1:257-265

Moravec F (1982) Proposal of a new systematic arrangement of nematodes of the family Capillariidae. Folia Parasitol 29:119-132

Moravec F (2001) Trichinelloid nematodes parasitic in cold-blooded vertebrates. Academia, Prague, $\mathrm{p} 430$

Saif YM (2008) Diseases of poultry, 12th edn. Blackwell Publishing Professional, Ames, p 1324
Skrjabin KI, Shikhobalova NP, Orlov IV (1957) Essentials of nematology. Trichocephalidae and Capillariidae of animals and man and diseases caused by them. vol. VI. Academy of Sciences of the USSR (Jerusalem, Israel Program for Scientific Translations, 1970), p 599

Tamaru M, Yamaki S, Jimenez LA, Sato H (2015) Morphological and molecular genetic characterization of three Capillaria spp. (Capillaria anatis, Capillaria pudendotecta, and Capillaria madseni) and Baruscapillaria obsignata (Nematoda: Trichuridae: Capillariinae) in avians. Parasitol Res 114:4011-4022

Thompson JD, Higgins DG, Gibson TJ (1994) CLUSTAL W: Improving the sensitivity of progressive multiple sequence alignment through sequence weighting, position-specific gap penalties and weight matrix choice. Nucleic Acids Res 22:4673-4680

Tran BT, Sato H, Luc PV (2015) A new Cosmocercoides species (Nematoda: Cosmocercidae), C. tonkinensis n. sp., in the scalebellied tree lizard (Acanthosaura lepidogaster) from Vietnam. Acta Parasitol 60:407-416

Varcasia A, Briant E, Tamponi C, Pipia AP, Cabras PA, Mereu M, DantasTorres F, Scala A, Otranto D (2015) Simultaneous infection by four feline lungworm species and implications for the diagnosis. Parasitol Res 114:317-321

Wakelin D (1963) Capillaria obsignata Madsen, 1945 (Nematoda) from the black swan. J Helminthol 37:381-386

Wakelin D (1964) A survey of the intestinal helminths parasitic in British domestic fowl. J Helminthol 38:191-200

Wakelin D (1965) On species of the genus Capillaria Zeder, 1800 (Nematoda) from British domestic fowl. Parasitology 55:285-301

Wehr EE (1936) Earthworms as transmitters of Capillaria annulata, the cropworm of the chickens. North Am Vet 17:18-20

Zhu X, Spratt DM, Beveridge I, Haycock P, Gasser RB (2000) Mithochondrial DNA polymorphism within and among species of Capillaria sensu lato from Australian marsupials and rodents. Int $\mathrm{J}$ Parasitol 30:933-938

Zucchero PJ (1942) Notes on the life cycle of Capillaria annulata. Proc West Va Acad Sci 15:96-106

Publisher's note Springer Nature remains neutral with regard to jurisdictional claims in published maps and institutional affiliations. 